\title{
Prototype Demonstration of Dual Sorbent Injection for Acid Gas Control on Municipal Solid Waste Combustion Units
}

Massachusetts Refusetech Inc.

Liberty Lane

Hampton, NH 03842

NREL technical monitor: Phil Shepherd

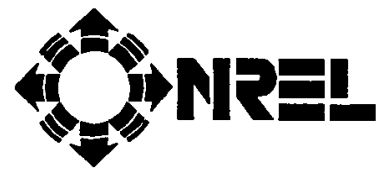

National Renewable Energy Laboratory 1617 Cole Boulevard Golden, Colorado 80401-3393

A national laboratory of the U.S. Department of Energy Operated by Midwest Research Institute for the U.S. Department of Energy

Under Contract No. DE-AC02-83CH10093

Under Subcontract No. TR-2-11293-1

May 1994 


\section{NOTICE}

NOTICE: This report was prepared as an account of work sponsored by an agency of the United States government. Neither the United States government nor any agency thereof, nor any of their employees, makes any warranty, express or implied, or assumes any legal liability or responsibility for the accuracy, completeness, or usefulness of any information, apparatus, product, or process disclosed, or represents that its use would not infringe privately owned rights. Reference herein to any specific commercial product, process, or service by trade name, trademark, manufacturer, or otherwise does not necessarily constitute or imply its endorsement, recommendation, or favoring by the United States government or any agency thereof. The views and opinions of authors expressed herein do not necessarily state or reflect those of the United States government or any agency thereof.

\section{Printed in the United States of America \\ Available from: \\ National Technical Information Service \\ U.S. Department of Commerce \\ 5285 Port Royal Road \\ Springfield, VA 22161 \\ Price: Microfiche A01 \\ Printed Copy AO4}

Codes are used for pricing all publications. The code is determined by the number of pages in the publication. Information pertaining to the pricing codes can be found in the current issue of the following publications which are generally available in most libraries: Energy Research Abstracts (ERA); Government Reports Announcements and Index (GRA and I); Scientific and Technical Abstract Reports (STAR); and publication NTIS-PR-360 available from NTIS at the above address. 


\begin{abstract}
Two independent dry alkali chemical injection systems were installed at a 1,500 tons per day waste-to-energy facility. The first system, injecting hydrated lime directly into the furnace of each of two 750 tons per day waste combustors, reduced sulfur dioxide $\left(\mathrm{SO}_{2}\right)$ emissions by $55 \%$ while consuming 5.4 pounds of hydrated lime per ton of municipal solid waste (MSW) processed. The second system, injecting sodium bicarbonate into ductwork downstream of the the furnaces (temperature range $750^{\circ} \mathrm{F}-1200^{\circ} \mathrm{F}$ ), was not capable of additional $\mathrm{SO}_{2}$ removal. Importantly, neither furnace injection of dry hydrated lime nor duct injection of dry sodium bicarbonate achieved any significant hydrogen chloride $(\mathrm{HCl})$ removal. In order to meet the United States Environmental Protection Agency (EPA) Emission Guidelines for acid gas control for very large existing municipal solid waste combustors, improvements to the acid gas removals which were achieved at the Massachusetts REFUSETECH Inc. facility during this test program would be necessary. The excellent mechanical reliability of dry injection systems was confirmed during this study.
\end{abstract}




\section{TABLE OF CONTENTS}

EXECUTIVE SUMMARY $\ldots \ldots \ldots \ldots \ldots \ldots \ldots \ldots$ i

NOMENCLATURE $\ldots \ldots \ldots \ldots \ldots \ldots \ldots$ iii

1.0 INTRODUCTION $\ldots \ldots \ldots \ldots \ldots \ldots \ldots \ldots \ldots \ldots \ldots \ldots \ldots \ldots \ldots$

1.1 Program Objectives . . . . . . . . . . . . . . . 1

1.2. Municipal Waste Combustion Regulatory Issues $\ldots \ldots \ldots \ldots \ldots 1$

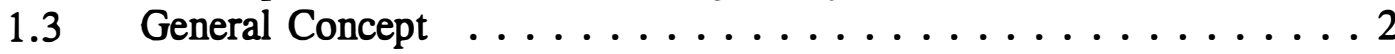

2.0 PROJECT DESCRIPTION $\ldots \ldots \ldots \ldots \ldots \ldots \ldots \ldots$

2.1 Project Organization $\ldots \ldots \ldots \ldots \ldots \ldots \ldots \ldots \ldots$

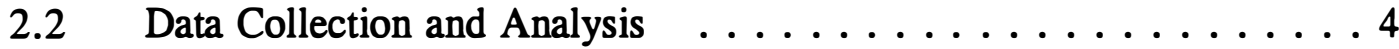

2.2.1 Continuous Emissions Monitoring System (CEMS) . . . . . 4

2.2.2 Determining Uncontrolled/Baseline Emissions . . . . . . . 4

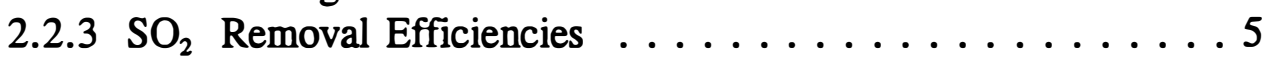

2.2.4 $\mathrm{HCl} \mathrm{Removal} \mathrm{Efficiencies} \mathrm{.} \mathrm{.} \mathrm{.} \mathrm{.} \mathrm{.} \mathrm{.} \mathrm{.} \mathrm{.} \mathrm{.} \mathrm{.} \mathrm{.} 5$

3.0 PROCESS DESCRIPTION $\ldots \ldots \ldots \ldots \ldots \ldots \ldots \ldots \ldots \ldots \ldots$

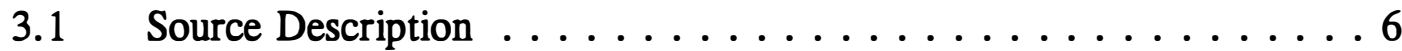

3.2 Emissions Controls .................6

4.0 DUAL SORBENT INJECTION SYSTEM $\ldots \ldots \ldots \ldots \ldots \ldots \ldots$

4.1 Furnace Sorbent Injection System $\ldots \ldots \ldots \ldots \ldots \ldots \ldots$

4.1 .1 Hydrated Lime . . . . . . . . . . . . . . 7

4.1.2 Injection Point Location Factors . . . . . . . . . . 7

4.1.3 Lime Feeder System Description . . . . . . . . . 8

4.1.4 Hydrated Lime Feeder Calibration . . . . . . . . . 8

$4.2 \quad$ Post Furnace Sorbent Injection System . . . . . . . . . . . 10

4.2.1 Sodium Bicarbonate . . . . . . . . . . . . . . 10

4.2.2 Injection Point Location Factors . . . . . . . . . . . . 10

4.2.3 Sodium Bicarbonate Feeder System Description . . . . . . 10

4.2.4 Sodium Bicarbonate Feeder Calibration . . . . . . . . 12

4.2.5 Materials Handling Problems . . . . . . . . . 12 


\section{TABLE OF CONTENTS (Cont.)}

5.0 COMPLETION OF PROJECT TASKS $\ldots \ldots \ldots \ldots \ldots$

5.1 Task 1: Start-up/Shake-down . . . . . . . . . . . . 13

5.1.1 Hydrated Lime - Furnace Sorbent Injection System . . . . . 13

5.1.2 Sodium Bicarbonate - Post Furnace Sorbent Injection System 13

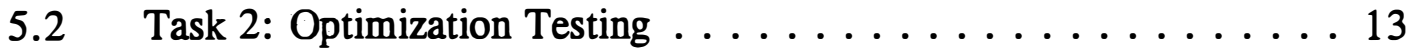

5.2 .1 Optimization Objectives . . . . . . . . . . . 13

5.2.2 Hydrated Lime - Manual Control Injection . . . . . . . 13

5.2.3 Hydrated Lime - Automatic Control Injection . . . . . . . . 14

5.2.4 Sodium Bicarbonate - Manual Control Injection . . . . . . . 14

5.3 Task 3: Long Term Testing . . . . . . . . . . . 15

5.4 Task 4: Manual Stack Testing $\ldots \ldots \ldots \ldots \ldots \ldots \ldots$

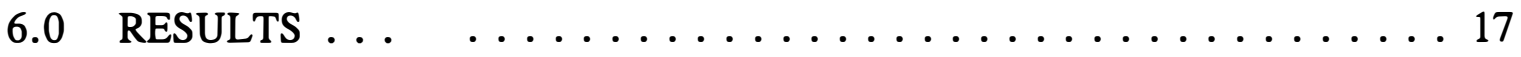

6.1 Summary of Results $\ldots \ldots \ldots \ldots \ldots \ldots \ldots$

6.2 Presentation of Optimization Results . . . . . . . . . 17

6.2.1 Hydrated Lime - Manual Control Injection . . . . . . . . . 17

6.2.2 Hydrated Lime - Automatic Control Injection . . . . . . . . . 19

6.2.3 Sodium Bicarbonate - Manual Control Injection . . . . . . . 19

6.3 Presentation of Long Term Testing Results . . . . . . . . . 23

6.3.1 $\mathrm{SO}_{2}$ Emissions and Removal Efficiencies . . . . . . . . 23

6.3.2 $\mathrm{HCl}$ Emissions and Removal Efficiencies ......... 23

6.3.3 Average Long-Term Lime Consumption . . . . . . . 28

6.4 Manual Stack Test Program Results . . . . . . . . . . . . 28

6.5 Operational Impacts $\ldots \ldots \ldots \ldots \ldots \ldots \ldots \ldots \ldots$

6.5.1 Mechanical Reliability of the System . . . . . . . . 28

6.5.2 Boiler Operational Impacts . . . . . . . . . . . . . 29

7.0 CONCLUSIONS AND RECOMMENDATIONS $\ldots \ldots \ldots \ldots \ldots$

7.1 Hydrated Lime $\ldots \ldots \ldots \ldots \ldots \ldots \ldots \ldots \ldots \ldots \ldots \ldots$

7.2 Sodium Bicarbonate $\ldots \ldots \ldots \ldots \ldots \ldots \ldots \ldots \ldots \ldots \ldots$

7.3 MWC Applicability . . . . . . . . . . . . . . 31 


\section{TABLE OF CONTENTS (Cont.)}

\section{List of Figures}

1. Alkali Chemical Injection into Furnace and Flue Gas Ductwork . . . 3

2. Hydrated Lime Storage and Conveying System . . . . . . . . . . 9

3. Sodium Bicarbonate Storage and Conveying System . . . . . . . 11

4. Flue Gas Sampling Ports Schematic . . . . . . . . . . . 16

5. $\mathrm{SO}_{2}$ Emissions and Lime Feed Rates - Manual Control . . . . . . 18

6. $\quad \mathrm{SO}_{2}$ Emissions and Lime Feed Rates - Automatic Control - Unit 1 . 20

7. $\mathrm{SO}_{2}$ Emissions and Lime Feed Rates - Automatic Control - Unit 2 . 21

8. $\quad \mathrm{HCl}$ Emissions Results .................. 22

9. $\mathrm{SO}_{2}$ Emissions Scatter Plot - Unit $1 \ldots \ldots \ldots \ldots \ldots \ldots$

10. $\mathrm{SO}_{2}$ Emissions Scatter Plot - Unit $2 \ldots \ldots \ldots \ldots \ldots \ldots \ldots$

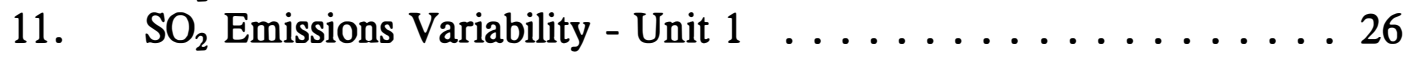

12. $\mathrm{SO}_{2}$ Emissions Variability - Unit $2 \ldots \ldots \ldots \ldots \ldots \ldots$

\section{List of Tables}

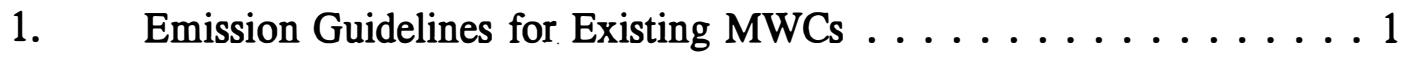

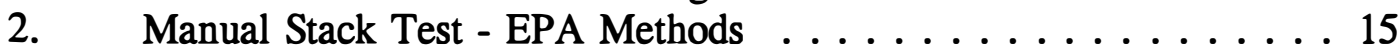

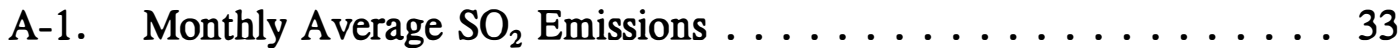

A-2. $\quad \mathrm{HCl}$ Emissions Test Results . . . . . . . . . . . . . 34

A-3. Hydrated Lime Feeder Calibration . . . . . . . . . . . . 35

A-4. Sodium Bicarbonate Feeder Calibration . . . . . . . . . 36

A-5. Lime Consumption and MSW Processed . . . . . . . . . 37

A-6. Emissions Test Results . . . . . . . . . . . . . . . . . . 38

Appendices

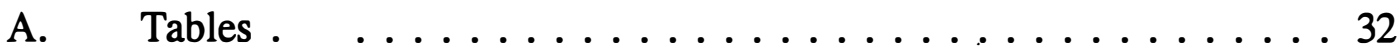

B. Sorbent Specifications $\ldots \ldots \ldots \ldots \ldots \ldots \ldots \ldots \ldots$ 


\section{EXECUTIVE SUMMARY}

\section{Purpose}

This research program was undertaken to gather and evaluate emissions and operations data associated with furnace injection of dry hydrated lime and duct injection of dry sodium bicarbonate at a commercial, 1,500 tons per day, waste-to-energy facility. The information compiled during the project adds to the current body of knowledge on the ability of these sorbents to affect acid gas emissions (sulfur dioxide and hydrogen chloride) from municipal solid waste combustors. This information is needed to accurately assess the capability of dry sorbent injection systems to meet the 1990 Clean Air Act and 1991 EPA Emission Guidelines requirements for existing municipal solid waste combustors.

\section{Method}

A Dual Sorbent Injection system was installed at the Massachusetts REFUSETECH Inc. facility in North Andover, Massachusetts to: (1) inject hydrated lime directly into the furnace and (2) inject sodium bicarbonate into ductwork downstream of the superheater section of both boilers at the facility.

Emissions data was analyzed for varying feed rates of both sorbents in order to determine the most efficient operating conditions. Long-term testing was performed in order to determine sorbent consumption rates, emissions data, boiler operational performance, and injection system reliability. A manual stack test was performed to determine the overall impact of sorbent injection on facility emissions of particulates, trace organics, and other pollutants. The project was subdivided into the following tasks: start-up/shake-down, optimization, long-term testing, and manual stack testing.

\section{Results and Conclusions}

System start-up and shake-down revealed that sorbent handling problems can have a serious impact on system functionality. Care should be taken during the system design and sorbent sizing specification stages to ensure free flow of sorbent from the storage area to the injection location. System optimization, utilizing the plant continuous emissions monitoring system, demonstrated that hydrated lime injection could successfully reduce sulfur dioxide $\left(\mathrm{SO}_{2}\right)$ emissions. Automatic control injection of hydrated lime proved effective in maintaining a preestablished $\mathrm{SO}_{2}$ emission limit. During the test program, an average $\mathrm{SO}_{2}$ removal of $55 \%$ was maintained at a lime feed rate of 5.4 pounds of lime per ton of MSW processed. The sodium bicarbonate injection system, however, was not able to measurably improve on the $\mathrm{SO}_{2}$ reductions achieved by the hydrated lime injection system alone (i.e., the expected additional $10 \%-20 \% \mathrm{SO}_{2}$ removal was not achieved with the addition of sodium bicarbonate injection). 
Long-term testing showed that the dry lime injection system is very reliable and requires minimal repair and maintenance. The actual mechanical reliability of the system surpassed the expected reliability of $98 \%$. Preventative maintenance has been performed during scheduled boiler outages, and the facility successfully avoided unscheduled outages due to any failure of the sorbent injection system.

Manual stack testing confirmed the furnace sorbent injection $\mathrm{SO}_{2}$ removal capability recorded by the facility continuous emissions monitoring system. However, neither sorbent displayed an ability to reduce hydrogen chloride emissions. In addition, particulate, nitrogen oxides, dioxins, and trace metals emissions did not appear to be influenced by the furnace injection of hydrated lime. 


\section{NOMENCLATURE}

$\begin{array}{ll}\mathrm{Btu} & \text { British thermal units } \\ \mathrm{Ca}: \mathrm{S} & \text { Calcium to Sulfur stoichiometric ratio } \\ \mathrm{CaO} & \text { Calcium Oxide } \\ \mathrm{Ca}(\mathrm{OH})_{2} & \text { Calcium Hydroxide (hydrated lime) } \\ \mathrm{CaSO} & \text { Calcium Sulfate } \\ \mathrm{CEM} & \text { Continuous Emissions Monitor } \\ \mathrm{CEMS} & \text { Continuous Emissions Monitoring System } \\ \mathrm{CO} & \text { Carbon Monoxide } \\ \mathrm{CO} & \text { Carbon Dioxide } \\ \mathrm{DOE} & \text { United States Department of Energy } \\ \mathrm{DEP} & \text { Massachusetts Department of Environmental Protection } \\ \mathrm{EPA} & \text { United States Environmental Protection Agency } \\ \mathrm{ESP} & \text { Electrostatic Precipitator } \\ \mathrm{FSI} & \text { Furnace Sorbent Injection (hydrated lime) } \\ \mathrm{GCP} & \text { Good Combustion Practices } \\ \mathrm{gr} / \mathrm{dscf} & \text { grains per dry standard cubic feet } \\ \mathrm{gr} / \mathrm{dscm} & \text { grains per dry standard cubic meter } \\ \mathrm{lb} / \mathrm{hr} & \text { pound per hour } \\ \mathrm{MSW} & \text { Municipal Solid Waste } \\ \mathrm{MWC} & \text { Municipal Waste Combustion unit } \\ \mathrm{MW} & \text { megawatts (megawatt hours per hour) } \\ \mathrm{NaCl} & \text { Sodium Chloride } \\ \mathrm{NaHCO} & \text { Sodium Bicarbonate } \\ \mathrm{NaSO} & \text { Sodium Sulfate } \\ \mathrm{ng} / \mathrm{dscm} & \text { Nanograms (10 } \\ \mathrm{NOx} & \text { Nitrogen Oxides } \\ \mathrm{NREL} & \text { National Renewable Energy Laboratory } \\ \mathrm{PCDD} / \mathrm{PCDF} & \text { PolyChlorinatedDibenzo-p-DioxinsandPolyChlorinated DibenzoFurans } \\ \mathrm{ppm} & \text { Parts Per Million } \\ \mathrm{PFSI} & \text { Post Furnace Sorbent Injection (sodium bicarbonate) } \\ \mathrm{REFUSETECH} & \text { Massachusetts REFUSETECH Inc. } \\ \mathrm{SDA} & \text { Spray Dryer Absorber } \\ \mathrm{SO}{ }_{2} & \text { Sulfur Dioxide } \\ \mathrm{TPD} & \text { Tons Per Day (Capacity) } \\ \mu \mathrm{g} / \mathrm{dscm} & \text { Micrograms (10 } \\ \mathrm{lb} \mathrm{HCl} / \mathrm{MMBtu} \text { grams) per dry standard cubic meter } \\ \mathrm{lb} \mathrm{SO} / \mathrm{MMBtu} & \text { pounds of HCl emissions per million Btu heat input } \\ & \text { pounds of SO }{ }_{2} \text { emissions per million Btu heat input } \\ & \end{array}$




\section{SECTION 1.0 \\ INTRODUCTION}

\subsection{PROGRAM OBJECTIVE}

The objective of this program was to conduct proof-of-concept tests on a dual chemical sorbent dry injection system at a commercial scale municipal solid waste combustion facility. The system performance was measured against the pending regulations for existing municipal waste combustors (MWCs). The program was undertaken in order to evaluate acid gas (sulfur dioxide and hydrogen chloride) reductions, to evaluate the effects on other regulated MWC emissions, and to provide needed design and performance information for dry sorbent injection systems for MWCs.

\subsection{MUNICIPAL WASTE COMBUSTION REGULATORY ISSUES}

In February 1991, EPA promulgated New Source Performance Standards in 40 CFR Part 60 for emissions from new MWCs in Subpart Ea, and Emission Guidelines for emissions from existing MWCs in Subpart Ca. The Emission Guidelines establish limitations on emissions of several pollutants which vary based upon the size of the facility (Table 1). For existing MWCs with capacities between 250 tons per day (TPD) and 1,100 TPD, the Emission Guidelines require that sulfur dioxide $\left(\mathrm{SO}_{2}\right)$ emissions not exceed $30 \mathrm{ppm}$ (all Emission Guidelines concentrations are in parts per million dry volume corrected to 7\% $\mathrm{O}_{2}$ ) or be reduced by at least $50 \%$, whichever limitation is the least stringent, and hydrogen chloride $(\mathrm{HCl})$ emissions not exceed $25 \mathrm{ppm}$ or be reduced by at least $50 \%$, whichever is least stringent. For existing MWCs with capacities above 1,100 TPD, $\mathrm{SO}_{2}$ emissions must be no greater than $30 \mathrm{ppm}$ or reduced by at least $70 \%$, whichever is least stringent, and $\mathrm{HCl}$ emissions must be no greater than $25 \mathrm{ppm}$ or reduced by at least $90 \%$, whichever is least stringent.

Table 1. Emission Guidelines for Existing MWCs

\begin{tabular}{|c|c|c||}
\hline 7 Emissions & MWC Capacity & M. \\
\hline & $250-1,100 \mathrm{TPD}$ & $>1,100 \mathrm{TPD}$ \\
\hline $\mathrm{SO}_{2}$ & $50 \%$ or $30 \mathrm{ppm}$ & $70 \%$ or $30 \mathrm{ppm}$ \\
\hline $\mathrm{HCl}$ & $50 \%$ or $25 \mathrm{ppm}$ & $90 \%$ or $25 \mathrm{ppm}$ \\
\hline Particulate & $0.030 \mathrm{gr} / \mathrm{dscf}$ & $0.015 \mathrm{gr} / \mathrm{dscf}$ \\
\hline PCDD/PCDF & $125 \mathrm{ng} / \mathrm{dscm}$ & $60 \mathrm{ng} / \mathrm{dscm}$ \\
\hline Opacity & $10 \%$ & $10 \%$ \\
\hline
\end{tabular}




\subsection{GENERAL CONCEPT}

The use of sorbent injection for emissions control in combustion plants is not new. Tests have been performed in coal-fired utility power plants under sponsorship of the Electric Power Research Institute and U.S. Department of Energy, using furnace injection of limestone or hydrated lime. These tests resulted in $\mathrm{SO}_{2}$ reductions on the order of $60 \%$ with calcium to sulfur stoichiometric ratios (Ca:S) approaching two to one (2:1). This indicates that even though there was twice the amount of calcium theoretically needed (100\% utilization) to react with all the $\mathrm{SO}_{2}$, the actual utilization of sorbent resulted in $60 \%$ reductions. Optimization of dry sorbent systems requires both the selection of a reactive sorbent and design of an injection system which maximizes utilization.

Several studies indicated that both hydrated lime and sodium bicarbonate were reactive sorbents, and would be good candidates for acid gas control at municipal solid waste combustors ${ }^{\mathbf{1 , 2 , 3}}$. Furnace injection of hydrated lime has been used for several years at the Alexandria, VA facility. However, there were no continuous, parametric data available from this facility. While some conclusions regarding $\mathrm{SO}_{2}$ reductions could be drawn from this prior work, limited information was available for predicting reductions of other gaseous emissions, trace organics or trace metals from furnace sorbent injection.

Massachusetts REFUSETECH Inc. (REFUSETECH) proposed combining furnace injection of hydrated lime with post-furnace injection of sodium bicarbonate as a method of obtaining increased acid gas control (Figure 1). It was anticipated that approximately $50 \% \mathrm{SO}_{2}$ removal could be accomplished by the furnace injection of hydrated lime, while sodium bicarbonate injection downstream of the furnace was expected to achieve additional $\mathrm{SO}_{2}$ removal. The additional $\mathrm{SO}_{2}$ removal could potentially allow the facility to meet the EPA Emission Guidelines for $\mathrm{SO}_{2}$ emissions for very large MWCs (i.e., greater than 1,100 TPD). Since $\mathrm{HCl}$ is a strong acid and usually more reactive than $\mathrm{SO}_{2}$, it was anticipated that $\mathrm{HCl}$ removal performance would also meet the Emission Guidelines requirements. 


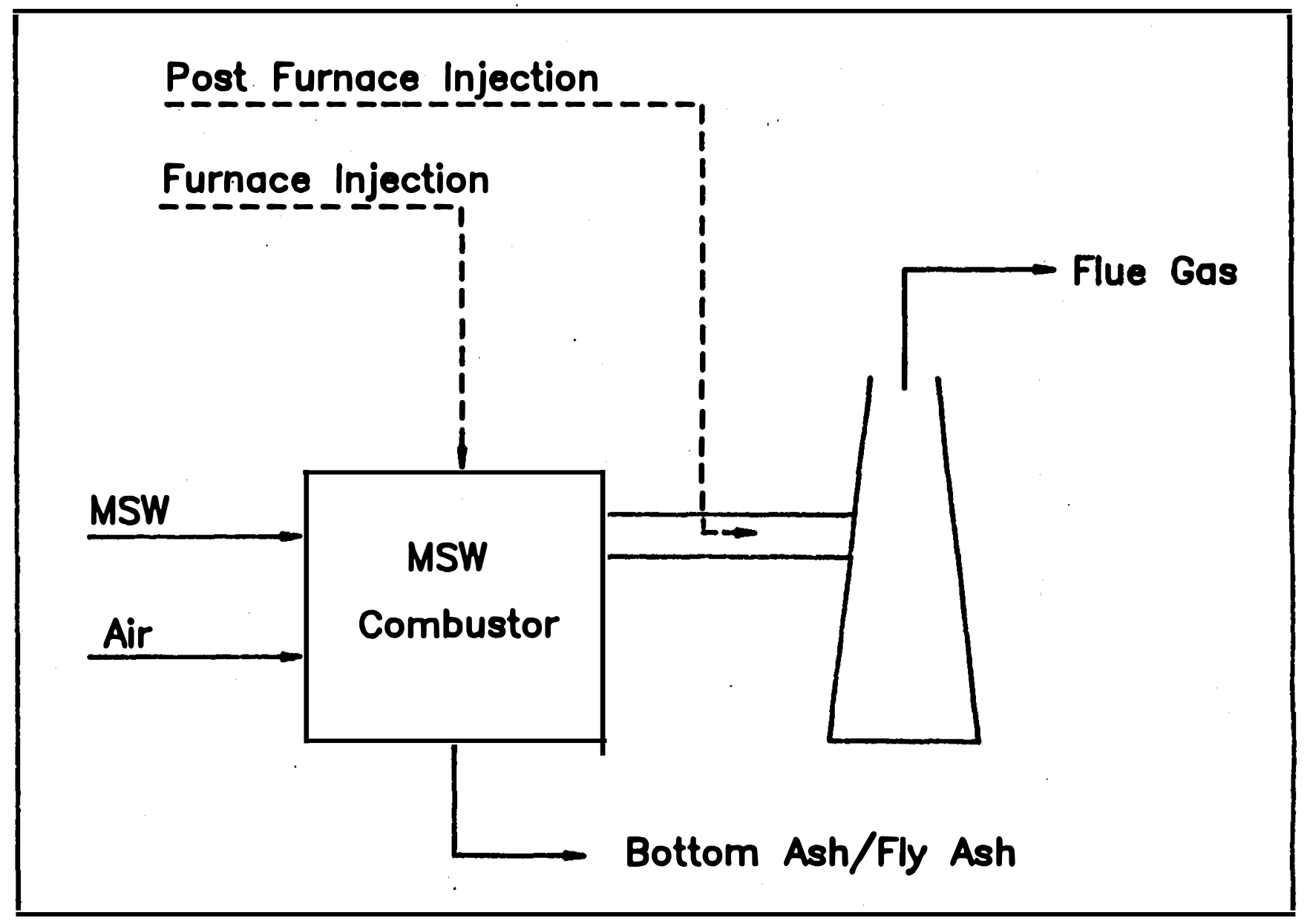

Figure 1. Alkali Chemical Injection into Furnace and Flue Gas Ductwork 


\section{SECTION 2.0 \\ PROJECT DESCRIPTION}

\subsection{PROJECT ORGANIZATION}

The project was subdivided into several specific tasks. Task 1 involved the start-up and mechanical/electrical shake-down of the dual sorbent injection system. Task 2 involved optimizing the feed rates of hydrated lime and sodium bicarbonate in order to evaluate a range of acid gas removal performance and to determine the most effective operating conditions for achieving the maximum acid gas emissions reductions. Task 3 involved long-term testing during which time the dual sorbent injection system reliability was evaluated. Task 4 involved a manual stack test, after the final optimum long-term operating conditions were established, to gather emissions data for hydrogen chloride ( $\mathrm{HCl})$, Total Suspended Particulates (TSP), trace organics (such as dioxins and furans), oxides of nitrogen (NOx), and trace metals.

\subsection{DATA COLLECTION AND ANALYSIS}

Data was collected by utilizing the facility's Continuous Emissions Monitoring System (CEMS), primarily for $\mathrm{SO}_{2}$ emissions, and an independent stack testing contractor for the performance of manual method stack tests. The emissions data collected during sorbent injection were compared to historical $\mathrm{SO}_{2}$ and $\mathrm{HCl}$ emissions levels collected prior to installation and operation of the sorbent injection system.

\subsubsection{Continuous Emissions Monitoring System (CEMS)}

The REFUSETECH facility utilizes a CEMS for the continuous monitoring for emissions of carbon monoxide (CO), carbon dioxide $\left(\mathrm{CO}_{2}\right), \mathrm{SO}_{2}, \mathrm{NOx}$, and Opacity. The CEMS is an extraction system equipped with a computerized data acquisition system. The facility CEMS meets all of the Massachusetts Department of Environmental Protection (DEP) and EPA CEM requirements. Annual relative accuracy test audits and quarterly cylinder gas audits are performed to demonstrate long-term CEM accuracy and reliability.

\subsubsection{Determining Uncontrolled/Baseline Emissions - Historical Data}

A municipal waste combustor that is equipped with a spray dryer absorber (SDA) for acid gas emissions controls normally measures uncontrolled emissions by sampling the flue gas from ductwork upstream of the SDA. Uncontrolled or baseline emissions as referred to in this report represent the average pollutant emission rates prior to the installation of the dual sorbent injection system. Hydrated lime injection controls the acid gases as they are formed in the furnace. This prevents the measurement of uncontrolled emissions prior to the application of pollution controls. At the REFUSETECH facility, extensive 
historical data was available for $\mathrm{SO}_{2}$ and $\mathrm{HCl}$ emissions prior to the installation of the dual sorbent injection system. This data was used to establish a baseline of uncontrolled emissions levels for evaluating the dual sorbent injection system performance.

\section{$\underline{2.2 .3 ~ S O}_{2}$ Removal Efficiencies}

Historical CEMS data was analyzed for the months of January, April, July, and October of the years 1991, 1992, and 1993. This data consists of one month of each quarter and includes periods both before and after installation of the sorbent injection systems. The CEMS data prior to installation of the sorbent injection systems were averaged to establish uncontrolled $\mathrm{SO}_{2}$ emissions levels. In Appendix A, Table A-1 summarizes the historical $\mathrm{SO}_{2}$ data by compiling the 24-hour block averages for each day of each month into an average $\mathrm{SO}_{2}$ emissions rate, in pounds of $\mathrm{SO}_{2}$ per million Btus of heat input (lb $\mathrm{SO}_{2} / \mathrm{MMBtu}$ ). Table A-1 also summarizes the average $\mathrm{SO}_{2}$ emission rates after the installation of the sorbent injection system, and the associated removal efficiencies.

\section{$\underline{2.2 .4 \mathrm{HCl} \text { Removal Efficiencies }}$}

The Commonwealth of Massachusetts requires that all MWCs conduct extensive stack gas emissions tests every nine months. The $\mathrm{HCl}$ data from historical manual stack tests, which were performed between May 1989 and the beginning of this research program, were averaged (Table A-2) and used as the baseline uncontrolled $\mathrm{HCl}$ emission value (0.751 lb $\mathrm{HCl} / \mathrm{MMBtu})$. Table A-2 also indicates the average $\mathrm{HCl}$ emisșions rates recorded during utilization of the hydrated lime furnace sorbent injection system, and the average $\mathrm{HCl}$ emissions recorded during use of the dual sorbent injection system (furnace sorbent injection of hydrated lime and post furnace sorbent injection of sodium bicarbonate). Other pollutant emissions data from these prior stack tests were used for comparative purposes also. 


\section{SECTION 3.0 \\ PROCESS DESCRIPTION}

\subsection{SOURCE DESCRIPTION}

REFUSETECH operates a 1,500 TPD waste-to-energy facility consisting of two 750 TPD combustion units. Refuse is received in an enclosed area and collected for storage in the adjacent refuse storage pit. The refuse is removed from the storage pit by two overhead cranes capable of feeding either of the two boilers. The crane deposits the refuse into furnace feed hoppers. Gravity then causes the refuse to flow downward to hydraulic ram feeders which regulate the flow of refuse fuel to the boilers where reciprocating grates move the refuse through the combustion chamber. Boiler design is mass-burn/water wall, with a maximum $172,500 \mathrm{lb} / \mathrm{hr}$ per boiler steam generating capacity. The steam drives a turbine-generator set and, after supplying internal power requirements, the plant sells 35.5 MW of electricity to New England Power Company.

\subsection{EMISSIONS CONTROLS}

Emissions controls on each waste-to-energy boiler include good combustion practices (GCP) and a three-field electrostatic precipitator (ESP) for particulate control to a 0.03 $\mathrm{gr} / \mathrm{dscf}$ (corrected to $12 \% \mathrm{CO}_{2}$ ) DEP limit. GCP consists of the use of independent primary and secondary combustion air automatically controlled to provide maximum combustion efficiency and ensure complete burning of the refuse. The REFUSETECH facility emissions controls also include a furnace sorbent injection system (FSI) to reduce $\mathrm{SO}_{2}$ emissions. The FSI system consists of a hydrated lime storage and pneumatic transport system which ensures delivery to the injection location. The injection nozzles are designed to ensure proper dispersion of hydrated lime throughout the furnace. 


\section{SECTION 4.0 \\ DUAL SORBENT INJECTION SYSTEM}

\subsection{FURNACE SORBENT INJECTION SYSTEM}

\subsubsection{Hydrated Lime}

The furnace sorbent injection (FSI) system injects hydrated lime directly into the furnace of the combustor. The hydrated lime injection occurs through the furnace sidewalls approximately six feet above the primary combustion zone. The injection point is located just below the secondary combustion air inlets; this secondary combustion air stream aids the dispersion of hydrated lime. At the high furnace temperatures $\left(2,000^{\circ} \mathrm{F}\right.$ and above), the hydrated lime is calcined, leaving highly porous calcium oxide, which reacts with the acid gases to form stable calcium compounds. The reaction products are carried along with the flue gas and are removed by the ESP. The basic reactions are:

$$
\begin{aligned}
& \mathrm{Ca}(\mathrm{OH})_{2}+\text { heat }-\mathrm{CaO}+\mathrm{H}_{2} \mathrm{O} \\
& 2 \mathrm{CaO}+2 \mathrm{SO}_{2}+\mathrm{O}_{2}-2 \mathrm{CaSO}_{4} \\
& 2 \mathrm{HCl}+1 / 2 \mathrm{O}_{2}-\mathrm{Cl}_{2}+\mathrm{H}_{2} \mathrm{O} \text { (Deacon Reaction) } \\
& \mathrm{CaO}+\mathrm{Cl}_{2}-\mathrm{CaCl}_{2}+1 / 2 \mathrm{O}_{2}
\end{aligned}
$$

\subsubsection{Injection Point Location Factors}

Factors influencing the location of hydrated lime injection include retention time, temperature, and turbulence. The goal of the FSI design was to achieve the most advantageous combination of these three factors. Sorbent injection into the furnace area represents the highest retention time possible with the current boiler arrangement. Temperatures of $2,000^{\circ} \mathrm{F}-2,500^{\circ} \mathrm{F}$ are common in the primary combustion zones where the hydrated lime injection occurs.

The combination of booster air, primary combustion air, and secondary combustion air aid the dispersion of hydrated lime throughout the furnace. Two injection nozzles on opposing sides of each boiler incorporate booster air to impart velocity onto the hydrated lime particles. Primary combustion air enters the combustion area from below the grates which move the waste through the boilers. Secondary combustion air enters the furnace area at a level just above the hydrated lime injection point. The combustion air entrains the hydrated lime particles and disperses them throughout the furnace. 


\subsubsection{Lime FeederSystem Description}

The hydrated lime is received by truck and is pneumatically conveyed into a 58'x13' cylindrical storage silo with a conical bottom discharge (Figure 2). The silo is equipped with a baghouse to prevent fugitive emissions during silo loading. The silo discharges the lime through two chutes each feeding an independent pneumatic lime conveying system. Hydraulic slide gates on these two chutes open allowing the lime to flow downward to variable speed screw feeders. The screw feeders discharge the hydrated lime into rotary air locks which separate the lime silo and screw feeders from the pressurized pneumatic system. Once the hydrated lime is discharged from the rotary air locks it is quickly entrained in the pressurized piping and is pneumatically conveyed by high pressure, high velocity air to the point of injection into the furnaces.

\subsubsection{Hydrated Lime Feeder Calibration}

A lime feeder calibration was performed to convert lime feeder output (in percent) into pounds of hydrated lime feed per hour. Feeder calibration occurred during a boiler outage since calibration required shutting down the air system and disconnecting the piping below the rotary air lock discharge. In manual control, constant lime feeder outputs were set and maintained for each collection period. Hydrated lime was collected from the rotary air lock discharge into containers for three and five minute periods. The container weights and collection times were compiled and the results were subjected to a linear regression analysis. The feeder calibration results indicated that each $1 \%$ increase in feeder output corresponded to an additional 12 pounds per hour of hydrated lime (Table A-3). 


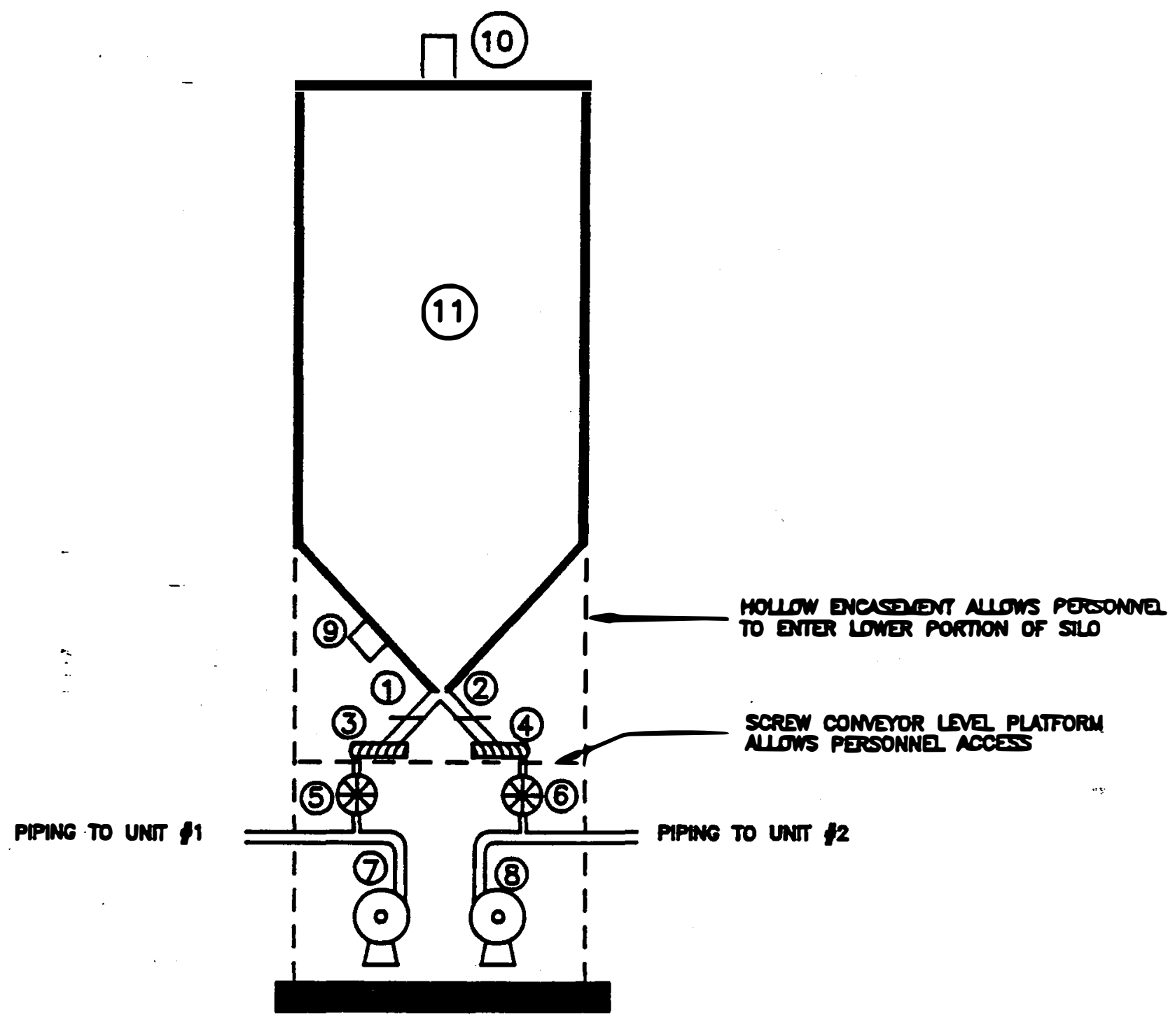

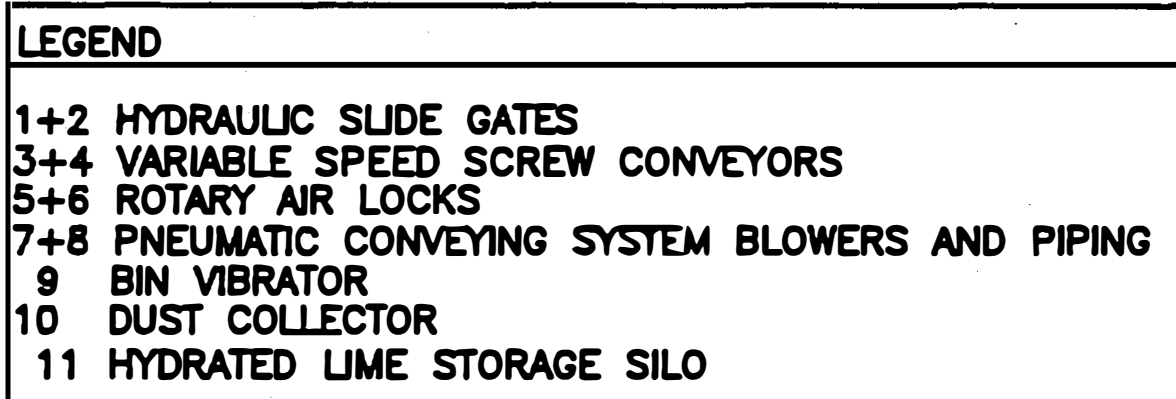

Figure 2. Hydrated Lime Storage and Conveying System 


\subsection{POST FURNACE SORBENT INJECTION (PFSI) SYSTEM}

\subsubsection{Sodium Bicarbonate}

The Project also investigated post-furnace sorbent injection of sodium bicarbonate to enhance the removal of acid gases from the flue gas. Figure 3 displays a schematic of the sodium bicarbonate storage and conveying system. Sodium compounds, created in the reaction between sodium bicarbonate and acid gases, and any unreacted sodium bicarbonate were entrained in the flue gas and removed by the ESP. The basic reactions of sodium bicarbonate in the flue gas are:

(1) $2 \mathrm{NaHCO}_{3}+\mathrm{SO}_{2}+1 / 2 \mathrm{O}_{2}-\mathrm{Na}_{2} \mathrm{SO}_{4}+2 \mathrm{CO}_{2}+\mathrm{H}_{2} \mathrm{O}$

(2) $\mathrm{NaHCO}_{3}+\mathrm{HCl} \rightarrow \mathrm{NaCl}+\mathrm{CO}_{2}+\mathrm{H}_{2} \mathrm{O}$

\subsubsection{Injection Point Location Factors}

As with the hydrated lime injection system, factors influencing the location of the sodium bicarbonate injection include retention time, temperature, and turbulence. Based on discussions with sodium bicarbonate vendors, more consideration was given to the need for maximizing retention time. This influenced the selection of the economizer inlet for the sodium bicarbonate injection location. This injection location allows for approximately three seconds reaction time. Temperatures at the economizer inlet vary with the boiler operating conditions, but usually remain in the range from $750^{\circ} \mathrm{F}-1,200^{\circ} \mathrm{F}$. Based on previous studies ${ }^{5}$, these temperatures were expected to be within the ranges for the chemical reaction to take place. The turbulence associated with the economizer inlet location is significant since the flue gas must make the arduous pass through the economizer tube banks and must make additional direction changes before entering the ESP, which increased the likelihood of intimate contact between the sorbent and the flue gas.

\subsubsection{Sodium Bicarbonate Feeder System Description}

The sodium bicarbonate is transported from its bulk storage silo to the injection location within the boiler house using a pneumatic conveying system (Figure 3). Once energized, the pneumatic air blowers operate on a continuous, steady-state basis. The sodium bicarbonate feed rate to each of two facility boilers is controlled independently by two variable speed screw feeders based upon either manual or automatic control. In the manual mode, the operator sets a controller at a fixed percent of total feeder output at which to run the feeders. The sodium bicarbonate is then fed at this constant rate until a change is made to the feeder setting. In the automatic mode, an electronic controller increases or decreases sodium bicarbonate feed in order to maintain the $\mathrm{SO}_{2}$ emissions, determined by the plant continuous emissions monitoring system, at a predetermined set point. 


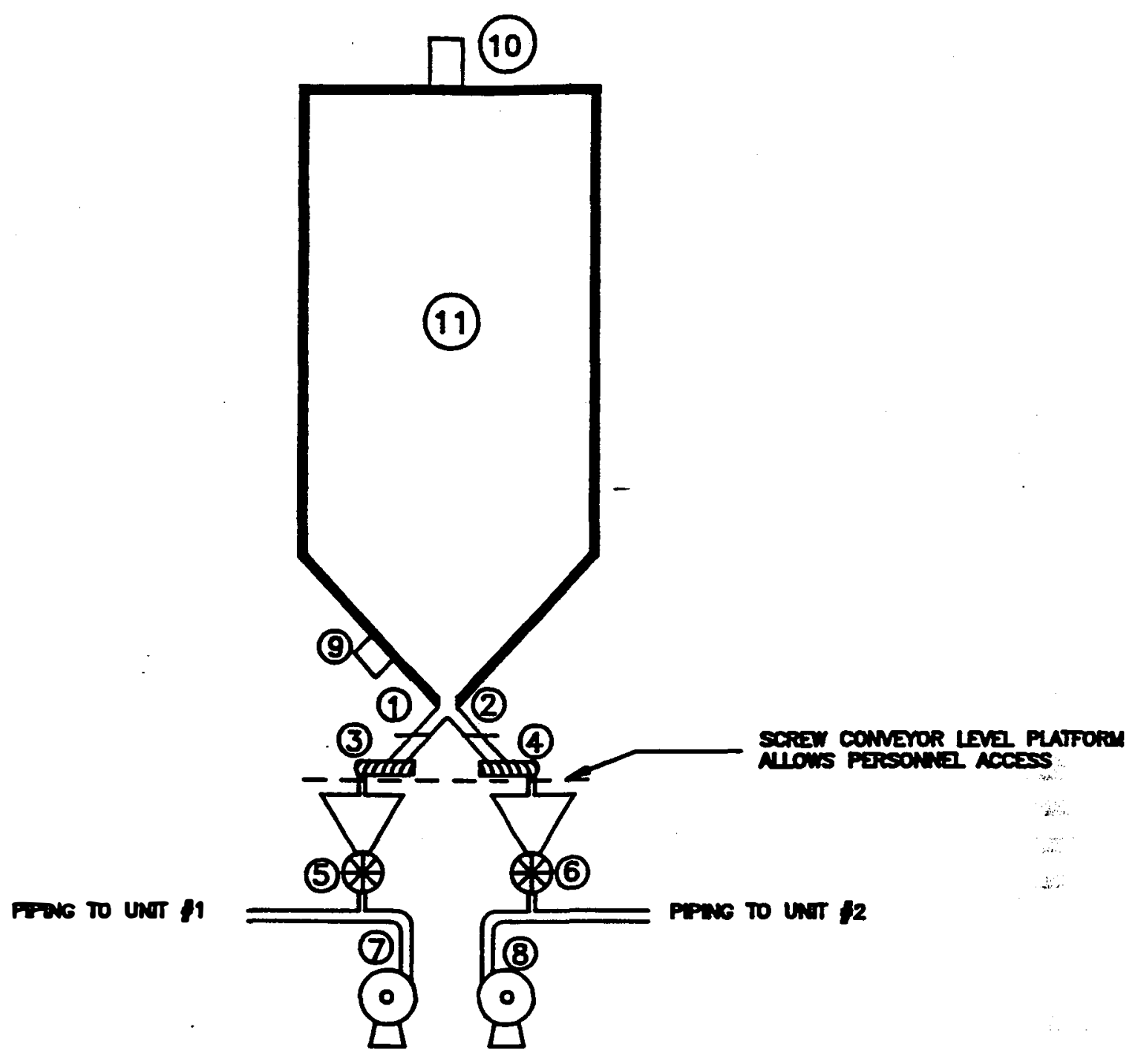

LEGEND
1+2 SUDE GATES
$3+4$ VARLABL SPEE SCREW CONVEERS
$5+6$ ROTARY NR LOCKS
$7+8$ PNEUMATC CONVING SYSTEM BLOWERS AND PIPING
9 BIN VBRATOR
10 DUST COUIECTOR
11 SODIUN BICARBONATE STORAGE SILO

Figure 3. Sodium Bicarbonate Storage and Conveying System 


\subsubsection{Sodium Bicarbonate Feeder Calibration}

As with the hydrated lime system, a sodium bicarbonate system feeder calibration was performed so that the percent of feeder output indication could be converted into pounds of sodium bicarbonate feed per hour. During the sodium bicarbonate feeder calibration, the plant used automatic control of hydrated lime injection as the primary acid gas control system, which enabled isolation of the sodium bicarbonate system while the boiler was online. The calibration required shutting down the sodium bicarbonate air system and disconnecting the piping below the rotary air lock discharge.

Operating the system in manual control, constant feeder outputs were set and maintained for each collection period. As the system was run at pre-set feed rates, sodium bicarbonate was collected from the rotary air lock discharge into pre-weighed containers for two minute periods. The calibration results indicated that each $1 \%$ increase in feeder output resulted in an additional 15 pounds per hour sodium bicarbonate feed (Table A-4).

\subsubsection{Materials Handling Problems}

Optimal particle sizing had to be determined during the initial stages of the sodium bicarbonate start-up. The first supply of sodium bicarbonate had a particle size of 30-100 microns, which did not flow quite as well as the hydrated lime. Subsequently, sodium bicarbonate with particle sizing less than or equal to 30 microns was used; this seemed to flow much better and was used thereafter. Specification sheets for the hydrated lime and sodium bicarbonate are included in Appendix B. 


\section{SECTION 5.0 COMPLETION OF PROJECT TASKS}

\subsection{TASK 1: START-UP/SHAKEDOWN}

\subsubsection{Hydrated Lime - Furnace Sorbent Injection System}

Construction of the FSI system required eight (8) weeks to complete. The lime silo was ordered three to four months before construction commenced. Separate conveying lines were installed for each of the two facility boilers. Each lime FSI system went through approximately 2-3 weeks of shakedown and systems start-up prior to commencing continuous operations. The hydrated lime FSI system was installed and operational on Unit \#1 one month prior to Unit \#2.

\subsubsection{Sodium Bicarbonate - Post Furnace Sorbent Injection System}

Construction of the sodium bicarbonate system began in August 1992. Since the sodium bicarbonate system was a custom design, several months were scheduled for the system start-up and shakedown.

\subsection{TASK 2: OPTIMIZATION TESTING}

\subsubsection{Optimization Objectives}

The objectives of the optimization program were to determine the maximum $\mathrm{SO}_{2}$ and $\mathrm{HCl}$ removal efficiencies achievable under the most effective sorbent utilization conditions. During optimization tests, the plant's certified CEMS and EPA manual test methods were used to evaluate the performance of the sorbent injection systems. Optimization testing consisted of both manual control and automatic control of hydrated lime injection. In addition to hydrated lime, sodium bicarbonate was injected using manual control of the feed rate.

\subsubsection{Hydrated Lime - Manual Control Injection}

The optimization program began with manually-controlled injection of hydrated lime at constant feed rates. Data were collected during eight hour test periods at each lime injection rate. At the end of each eight hour test period, a higher lime injection rate was chosen for the next eight hour period. During the manual control injection program it was discovered that lime retained in the furnace resulted in reduced $\mathrm{SO}_{2}$ emissions in the hours immediately following the highest lime feed rates. Using increasingly lower lime feed rates would have indicated $\mathrm{SO}_{2}$ reductions, which would have misrepresented the $\mathrm{SO}_{2}$ removal efficiencies at each injection rate. The use of increasingly higher lime injection rates was a conscious attempt to avoid residual effects. 


\subsubsection{Hydrated Lime - Automatic Control Injection}

Objectives of the automatic control injection optimization program were to investigate the feasibility of automatic emissions control and to obtain lime consumption data while maintaining $\mathrm{SO}_{2}$ emission levels below a pre-established limit with an automatic set-point. Automatic control injection utilizes the plant CEMS in conjunction with the automatic lime feed controller to vary lime use based on $\mathrm{SO}_{2}$ emissions. The lime feed controller receives $\mathrm{SO}_{2}$ emissions data and automatically increases or decreases the lime screw feeder rotational speed in order to increase or decrease the rate of the lime feed. Under normal conditions, increasing lime feed rate tends to decrease the $\mathrm{SO}_{2}$ emissions levels. Automatic control injection allows lime consumption to vary based upon $\mathrm{SO}_{2}$ emissions as opposed to remaining constant with manual control injection. Therefore, periods of reduced $\mathrm{SO}_{2}$ emissions results in reduced lime consumption, making automatic control injection more efficient, in terms of hydrated lime consumption, than manual control injection.

In addition, the automatic controller reacts quickly to increases in $\mathrm{SO}_{2}$ emissions, increasing the lime feed to reduce $\mathrm{SO}_{2}$ emissions. During automatic control injection, the system was successful in maintaining $\mathrm{SO}_{2}$ emissions below the pre-established limits.

\subsubsection{Sodium Bicarbonate - Manual Control Injection}

The optimization program also included evaluation of sodium bicarbonate post-furnace injection in conjunction with furnace injection of hydrated lime for the reduction of $\mathrm{HCl}$, $\mathrm{SO}_{2}$, and possibly NOx emissions. The plant CEMS was used to compile $\mathrm{SO}_{2}$ and $\mathrm{NOx}$ data. In addition, Entropy Environmentalists Inc. performed EPA Method 26 manual stack tests for the determination of $\mathrm{HCl}$ emissions, during two days of simultaneous furnace injection of hydrated lime and post-furnace injection of sodium bicarbonate.

Operation of the Dual Sorbent Injection system was performed under four conditions during the test period. Three, one-hour tests were performed under each of the four sorbent injection conditions. Condition One was a baseline, or control condition, consisting of automatic hydrated lime injection with a set point of $70 \mathrm{ppm} \mathrm{SO}_{2}$, uncorrected. Conditions Two, Three, and Four were under the same hydrated lime injection conditions, however, sodium bicarbonate was introduced at three different stoichiometric feed rates, assuming that baseline $\mathrm{HCl}$ emission levels would be comparable to historical levels. Condition Two was a 1:1 stoichiometric ratio of sodium bicarbonate to anticipated $\mathrm{HCl}$ levels. Since each mole of sodium bicarbonate can react with one mole of $\mathrm{HCl}$, under a 1:1 stoichiometric ratio, the elimination of $\mathrm{HCl}$ would require $100 \%$ sorbent utilization. Higher stoichiometric ratios were also used since $100 \%$ sorbent utilization was not expected. Condition Three was a 1.5:1 stoichiometric ratio of sodium bicarbonate to anticipated $\mathrm{HCl}$ levels. Condition Four was a 2:1 stoichiometric ratio of sodium bicarbonate to anticipated $\mathrm{HCl}$ levels. 


\subsection{TASK 3: LONG-TERM TESTING}

The long-term testing program did not include data on the injection of sodium bicarbonate. Since no additional $\mathrm{SO}_{2}$ or $\mathrm{HCl}$ removal could be linked to the injection of sodium bicarbonate (see Section 6.2.3), the injection of this sorbent was discontinued. In order to measure the effectiveness of the lime injection system over an extended test period, data were collected throughout the summer months of 1993.

\subsection{TASK 4: MANUAL STACK TESTING}

During October 1993, a manual stack emissions testing program was performed by Entropy Environmentalists. Prior to performance of the stack test, a protocol was submitted to and approved by the DOE's National Renewable Energy Laboratory. The manual stack test consisted of one full week of EPA methods testing for particulates, trace metals, organics, and other emissions. The following EPA test methods were utilized; $1-4,5,6,7,10 \mathrm{~B}, 13 \mathrm{~B}, 23$, Draft 29, and 101A. Figure 4 shows a schematic of the test port locations which were accessed by the contractor during the manual stack test. According to the original research plan, manual testing was to be conducted at the final optimum lime and sodium bicarbonate injection conditions established during the optimization testing. Optimum conditions represent the most cost-effective lime and sodium bicarbonate injection rates or combination meeting a pre-established emissions limit of $0.27 \mathrm{lb} \mathrm{SO}_{2} / \mathrm{MMBTU}$ (approximately $100 \mathrm{ppm}$ ). As previously indicated, injection of sodium bicarbonate did not result in significant reductions in $\mathrm{SO}_{2}$. This resulted in the use of furnace injection of hydrated lime as the sole sorbent and technology for control of acid gas emissions during the stack test.

Tests were performed by the contractor in accordance with approved EPA test methods contained in Appendix A of 40 CFR Part 60. All equipment used during the testing was certified for the intended testing and properly calibrated according to the relevant EPA test method protocol. Accordingly, field blanks were required for trace metals and organics.

Table 2. Manual Stack Test - EPA Methods

\begin{tabular}{|c|c|c|c|}
\hline Parameter & Test Method & Parameter & Test Method \\
\hline Particulate & $1-5$ & Nitrogen Oxides & 7 \\
\hline Trace Metals & 29 Draft/MMTL & Carbon Monoxide & 10 \\
\hline Organics & 23 & Flourides/HCl & 13B \\
\hline Sulfur Dioxide & 6 & Mercury & $101 \mathrm{~A}$ \\
\hline
\end{tabular}




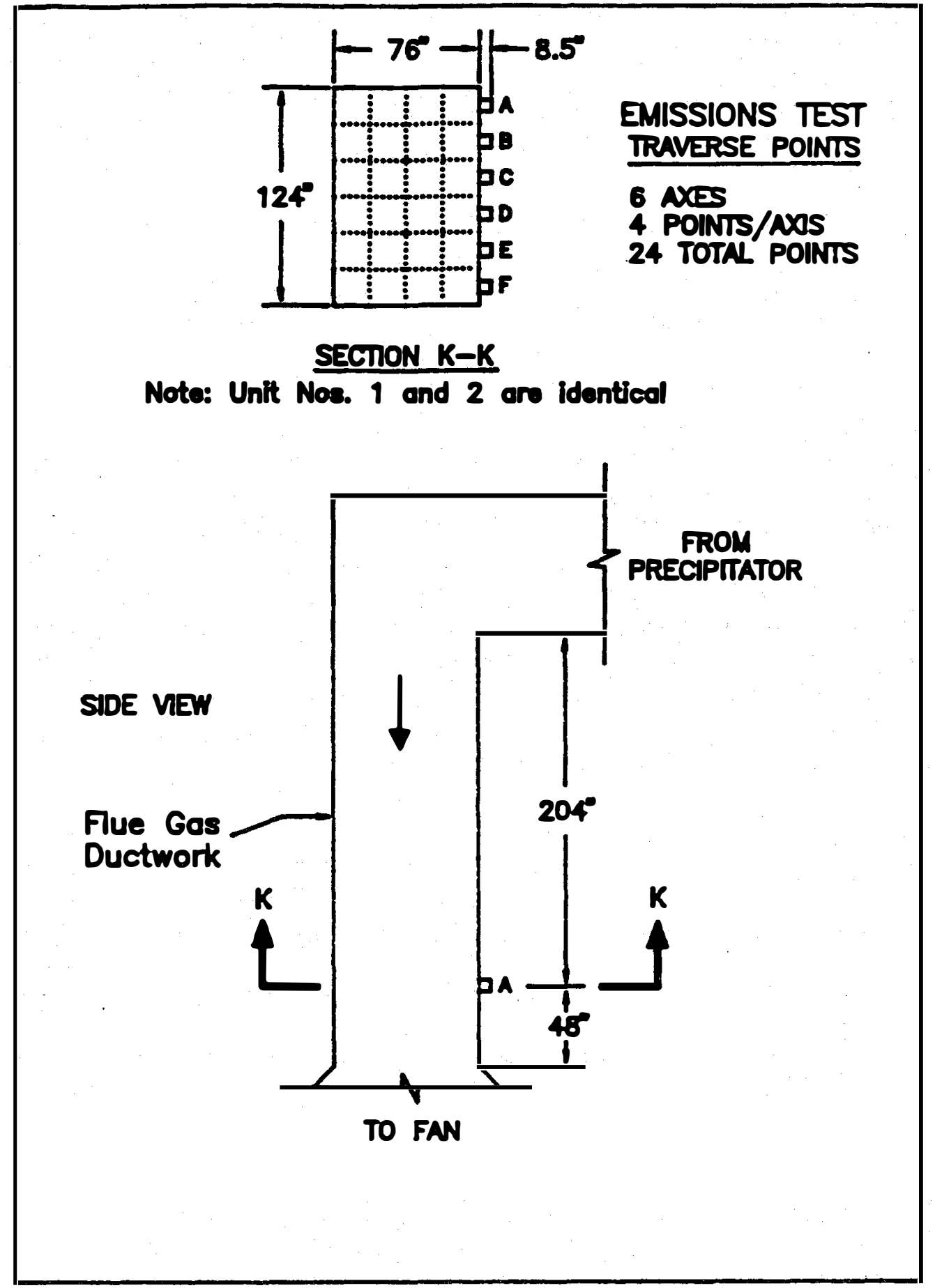

Figure 4. Flue Gas Sampling Ports Schematic 


\section{SECTION 6.0 RESULTS}

\subsection{SUMMARY OF RESULTS}

The program objective has been accomplished. A proof-of-concept test has been completed for a dual sorbent injection system at a commercial scale municipal solid waste combustion facility. The emissions reductions achieved by the dual sorbent injection system would not be sufficient to meet the $\mathrm{SO}_{2}$ or $\mathrm{HCl}$ requirements of the Emission Guidelines for existing MWCs above 1,100 tpd capacity. Still, a smaller facility (less than 1,100 tpd capacity) would meet the Emission Guidelines for $\mathrm{SO}_{2}$ reductions if it was capable of utilizing lime injection to maintain the $\mathrm{SO}_{2}$ reductions observed during long-term testing at REFUSETECH (55\% $\mathrm{SO}_{2}$ reduction). However, the other Emission Guidelines requirements would need to be addressed.

\subsection{PRESENTATION OF OPTIMIZATION RESULTS}

\subsubsection{Hydrated Lime - Manual Control Injection}

Graphical analysis of the manually-controlled injection portion of the optimization tests displays the $\mathrm{SO}_{2}$ removal capabilities of hydrated lime injection. Figure 5 shows that at higher manual lime injection feed rates, the plant CEMS indicated higher $\mathrm{SO}_{2}$ reductions.

During the manually-controlled hydrated lime injection portion of the optimization program, the facility experienced short-term $\mathrm{SO}_{2}$ spikes at reduced hydrated lime feed rates. The short-term spikes lasted from a few minutes to more than an hour, during which time the optimization program was interrupted while necessary corrective actions, such as increased lime feed, were taken in order to reduce $\mathrm{SO}_{2}$ emissions. The short-term $\mathrm{SO}_{2}$ emissions were reduced to normal levels, and, therefore, did not result in elevated average $\mathrm{SO}_{2}$ emissions.

At a Ca:S stoichiometric ratio above 2:1 (above 200 pounds of lime per hour) the FSI system was able to achieve an overall $\mathrm{SO}_{2}$ reduction of $50 \%$ on a consistent, reliable basis. Short-term $\mathrm{SO}_{2}$ emission removal rates approaching $80 \%$ were achievable, but required lime feed rates above 400 pounds per hour (i.e., a Ca:S stoichiometric ratio of $4: 1)$. 


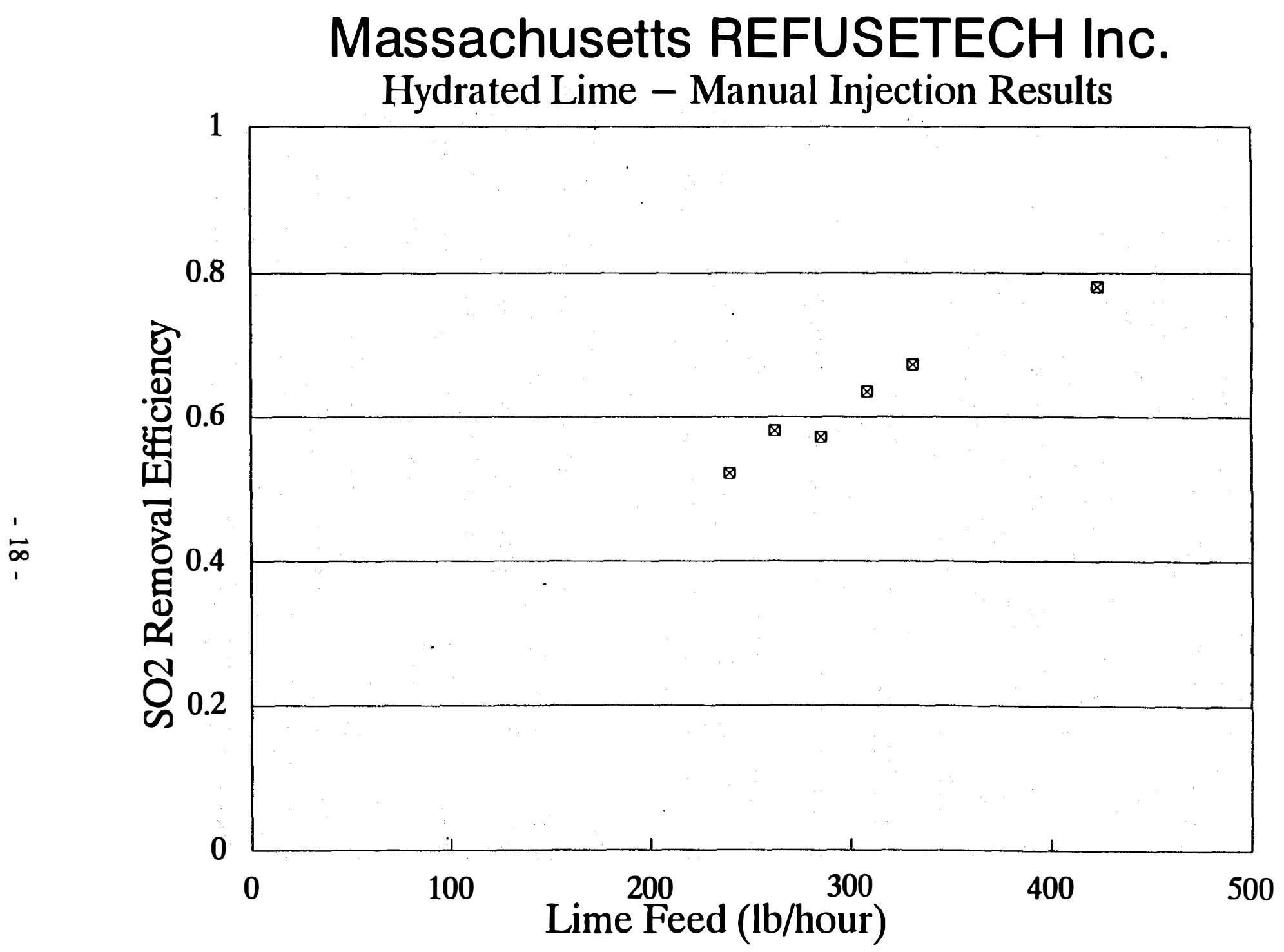

Figure 5. $\mathrm{SO}_{2}$ Emissions and Corresponding Hydrated Lime Feed Rates - Manual Control 


\subsubsection{Hydrated Lime - Automatic Control Injection}

Figure 6 and Figure 7 show 24-hour block average $\mathrm{SO}_{2}$ levels and the corresponding lime feed rates for Boiler $\# 1$ and Boiler $\# 2$, respectively. The graphs indicate that automatic control injection of hydrated lime was able to maintain $\mathrm{SO}_{2}$ emissions below a fixed limit, even with the inherent variability in $\mathrm{SO}_{2}$ generation in the furnace. However, lime consumption and $\mathrm{SO}_{2}$ emissions rates are not perfectly correlated and can vary considerably over the course of one week. In addition, lime consumption was generally increased for a short period (one week) following boiler cleaning. This can be seen graphically in Figure 6 as the average lime feed rate spike following the Unit 1 boiler outage (June 17). Three daily average data points show lime consumption significantly higher immediately following a boiler cleaning. The increased lime consumption diminished after about one week and normal lime consumption rates resumed.

\subsubsection{Sodium Bicarbonate - Manual Control Injection}

Manual stack testing for the determination of $\mathrm{HCl}$ emissions was performed during the May 1993 sodium bicarbonate optimization program, during which time the hydrated lime system was operated using automatic control. Sodium bicarbonate feed rates were manually controlled during this optimization program. Sodium bicarbonate feed rates included four conditions, representing $\mathrm{Na}: \mathrm{Cl}$ stoichiometric ratios of $0: 1,1: 1,1.5: 1$, and 2:1. Manual stack test data from the sodium bicarbonate optimization program indicated that neither hydrated lime injection alone nor hydrated lime injection coupled with sodium bicarbonate injection reduced $\mathrm{HCl}$ emissions at the facility.

Table A-2 and Figure 8 contain $\mathrm{HCl}$ emissions data for the REFUSETECH facility for periods prior to installation of the sorbent injection systems, for periods of hydrated lime injection as the sole chemical sorbent, and for periods of simultaneous injection of both hydrated lime and sodium bicarbonate sorbents. The historical analysis of $\mathrm{HCl}$ levels show that the average $\mathrm{HCl}$ emissions levels were not meaningfully reduced by either lime injection or simultaneous injection of lime and sodium bicarbonate. Since there were no significant reductions in $\mathrm{HCl}$ emissions, no $\mathrm{HCl}$ removal efficiencies were calculated. 


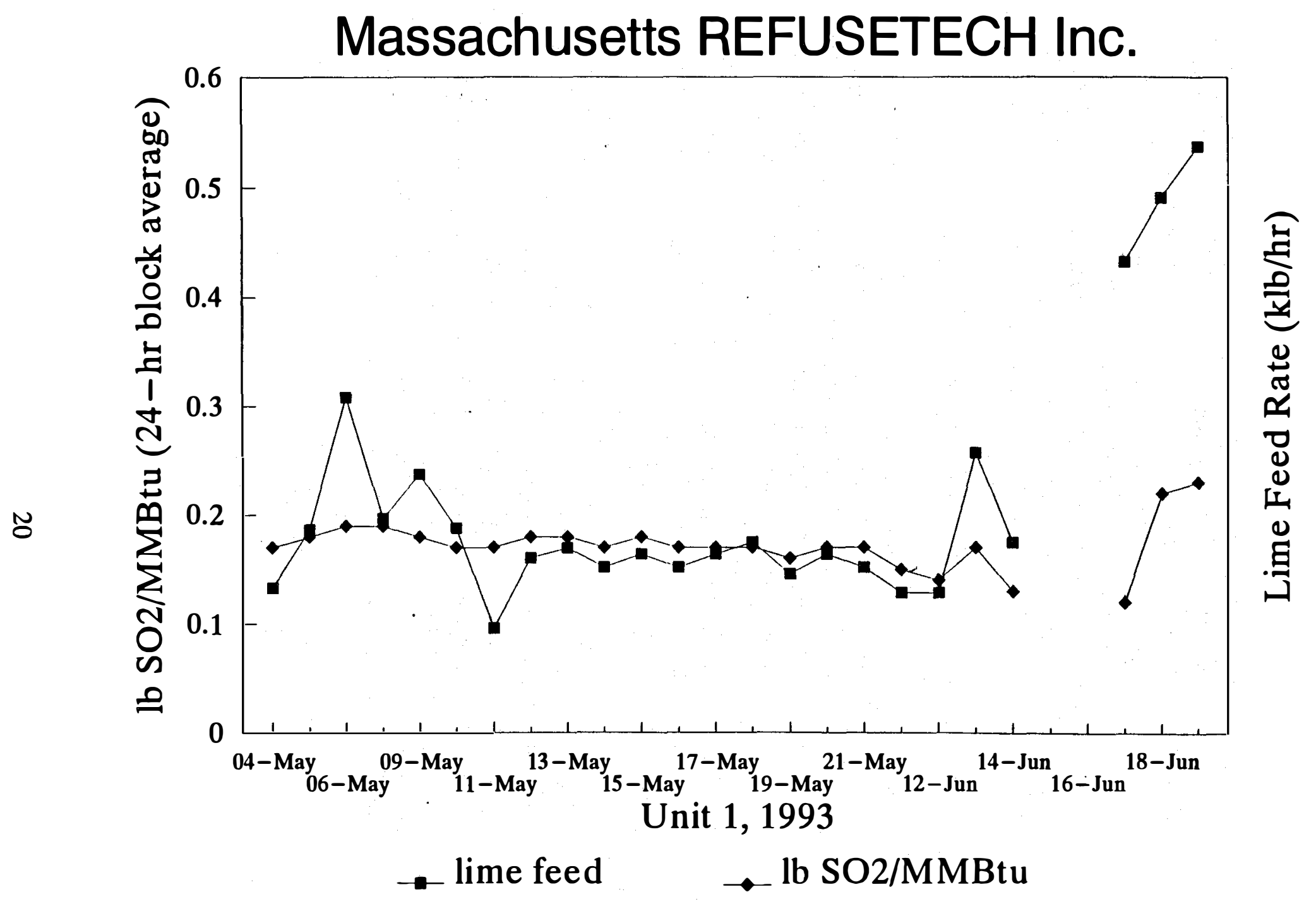

Figure 6. $\mathrm{SO}_{2}$ Emissions and Corresponding Hydrated Lime Feed Rates - Automatic Control 


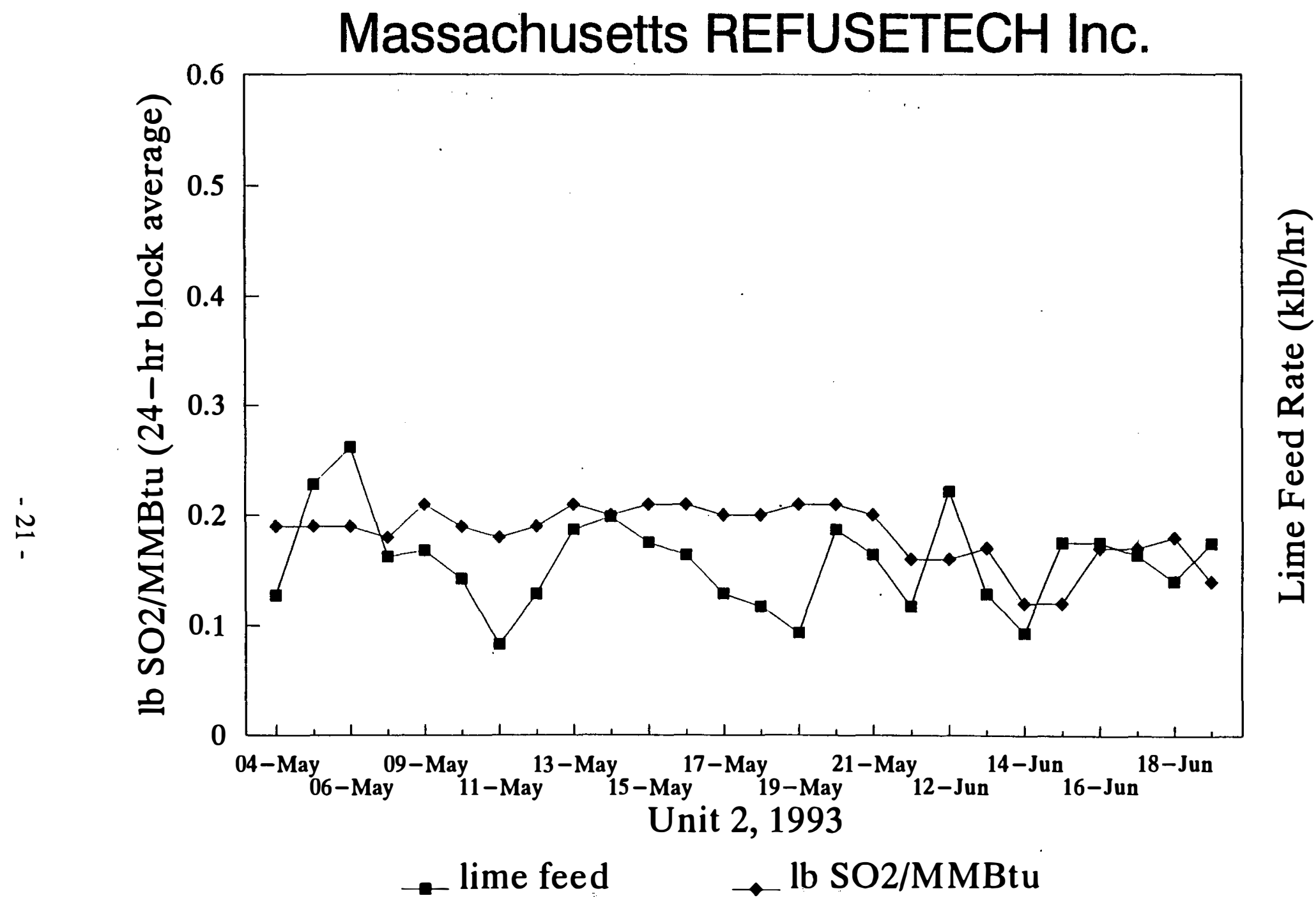

Figure 7. $\mathrm{SO}_{2}$ Emissions and Corresponding Hydrated Lime Feed Rates - Automatic Contro1 


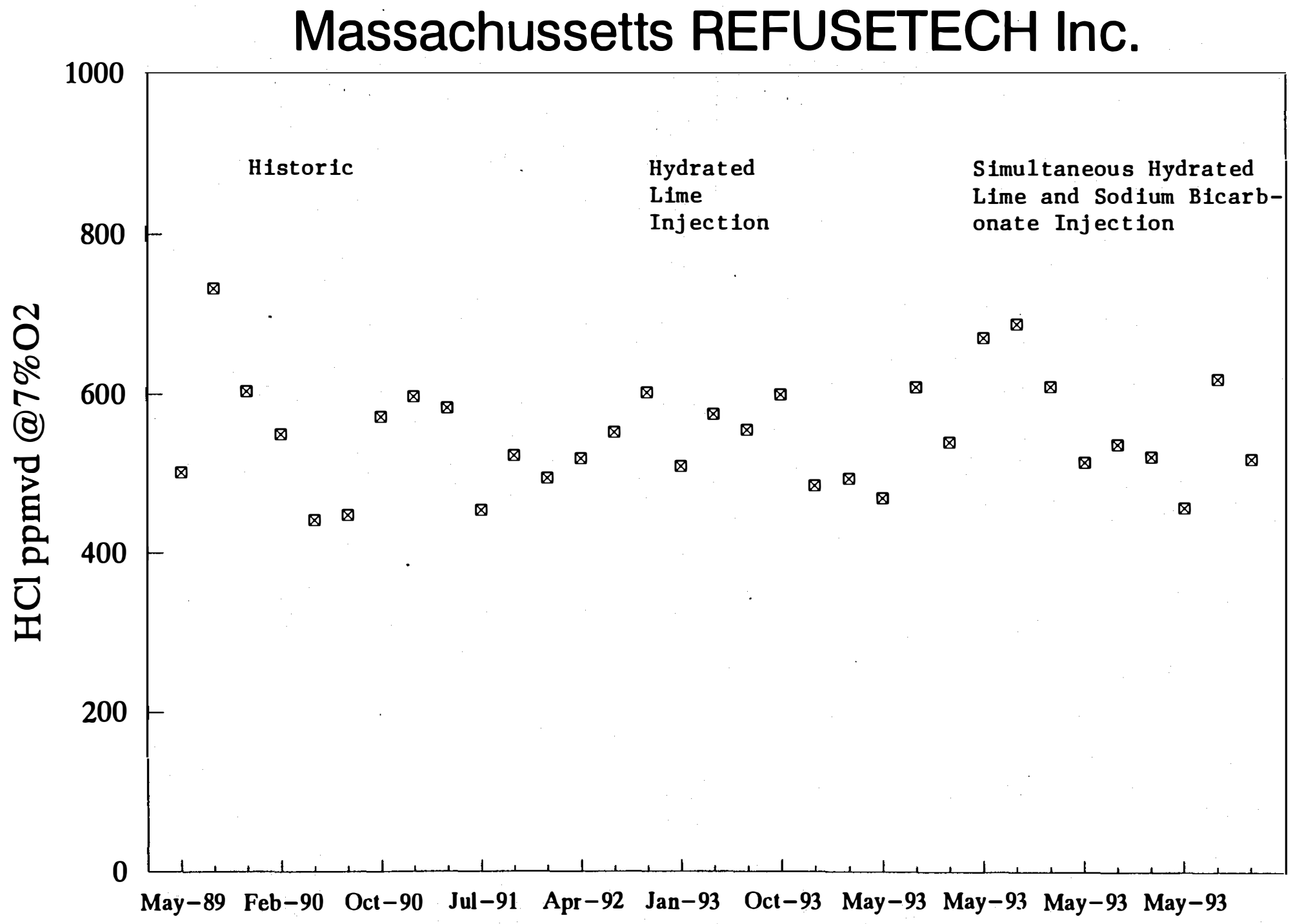

Figure 8. Comparison of Historic HC1 Emissions with HC1 Emissions During Hydrated Lime Injection and with HC1 Emissions During Simultaneous Injection of Hydrated Lime and Sodium Bicarbonate 


\subsection{PRESENTATION OF LONG-TERM TESTING RESULTS}

Sustained $\mathrm{SO}_{2}$ reductions at or above $50 \%$ were achieved during long-term testing of the hydrated lime injection system. In addition, the lime injection system has proven very reliable over long periods. The actual mechanical availability of the lime injection system has surpassed expectations, and solving the material handling challenges posed by both the lime and sodium bicarbonate systems has expanded the existing knowledge base for those who wish to use this technology in the future.

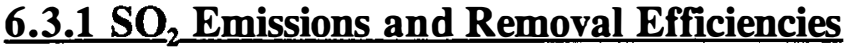

Although the two sorbents working in conjunction did not amplify $\mathrm{SO}_{2}$ reductions, reductions on $\mathrm{SO}_{2}$ emissions of $55 \%$ were achieved during long-term injection of hydrated lime into the furnace of the REFUSETECH units. A comparison of historic $\mathrm{SO}_{2}$ levels with test results, plotted on scatter plots in Figures 9 and 10, shows the significant reductions in $\mathrm{SO}_{2}$ emissions resulting from the use of the hydrated lime injection system.

In addition to displaying the reductions in $\mathrm{SO}_{2}$ emissions achieved by the hydrated lime injection system, Figures 11 and 12 also illustrate the reduction in $\mathrm{SO}_{2}$ emissions variations (i.e., $\mathrm{SO}_{2}$ spikes). The reduced standard deviations of the data points clearly shows that the furnace sorbent injection system can effectively control $\mathrm{SO}_{2}$ emissions levels.

\subsubsection{HCl Emissions and Removal Efficiencies}

The $\mathrm{HCl}$ emission levels encountered during the manual stack test were similar to $\mathrm{HCl}$ emissions levels recorded from manual stack tests performed prior to the installation of the dual sorbent injection system. The test data (Table A-2 and Figure 8) did not show meaningful reductions in $\mathrm{HCl}$ emissions. If the reaction of hydrated lime with $\mathrm{HCl}$ occurs as a two step process beginning with the Deacon Reaction as shown in equations (3) and (4) in Section 4.1.1, the high furnace temperatures may be inhibiting $\mathrm{HCl}$ removal. Equilibrium of the Deacon Reaction shifts strongly to the left above $1400^{\circ} \mathrm{F}^{6}$. The high furnace temperatures may be shifting the equilibrium of reaction (3) to the left leaving little or no $\mathrm{Cl}_{2}$ to react with $\mathrm{Ca}(\mathrm{OH})_{2}$, as shown in reaction (4). Research indicates that as injection temperature increases from $260^{\circ} \mathrm{F}$ to $1320^{\circ} \mathrm{F}$, the effectiveness of calcium in capturing $\mathrm{HCl}$ as $\mathrm{CaCl}_{2}$ is reduced from $90 \%$ to $1 \%^{6}$. 
Massachusetts REFUSETECH Inc. UNIT 1

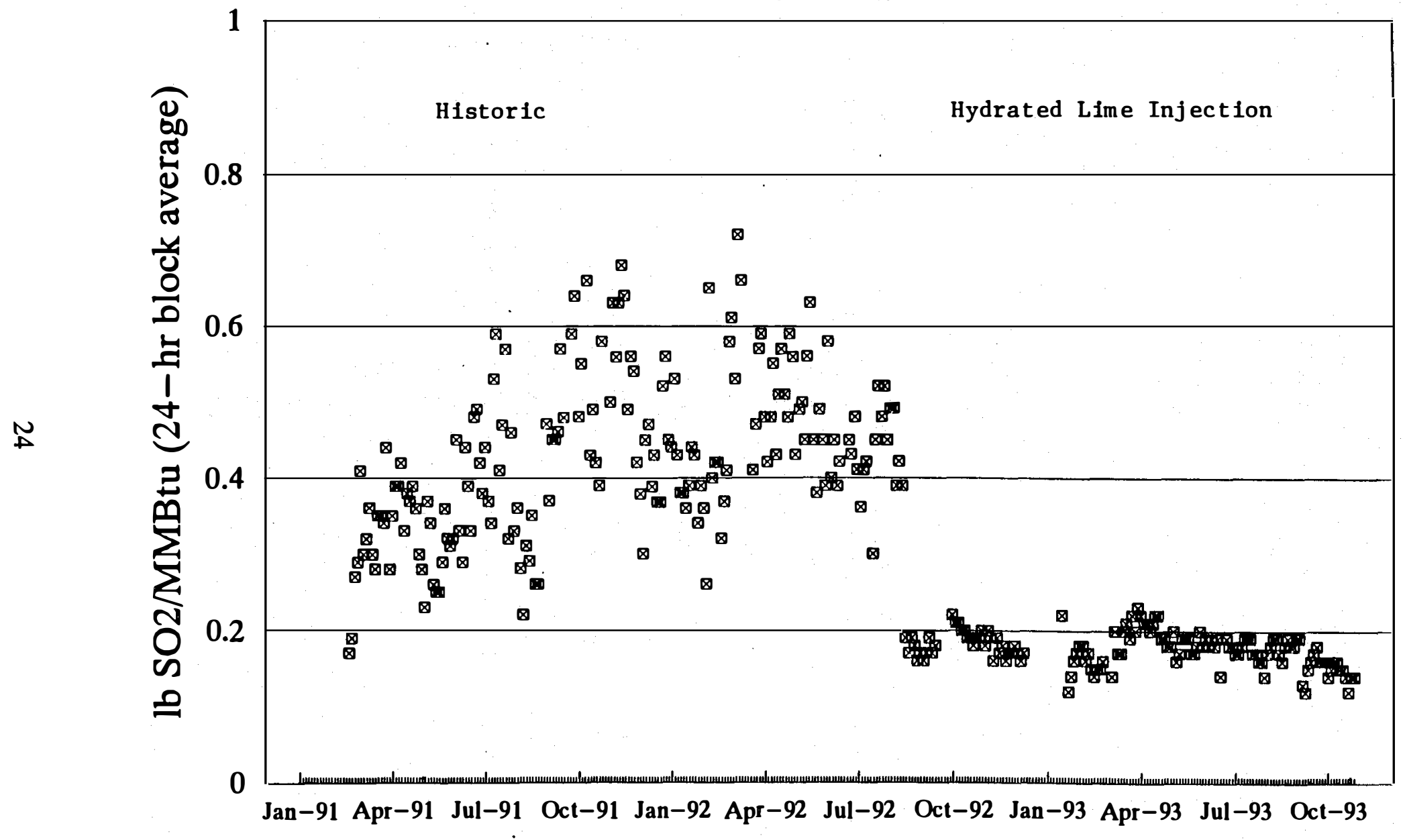

Figure 9. Comparison of Historic $\mathrm{SO}_{2}$ Emissions with $\mathrm{SO}_{2}$ Emissions During Hydrated Lime Injection 


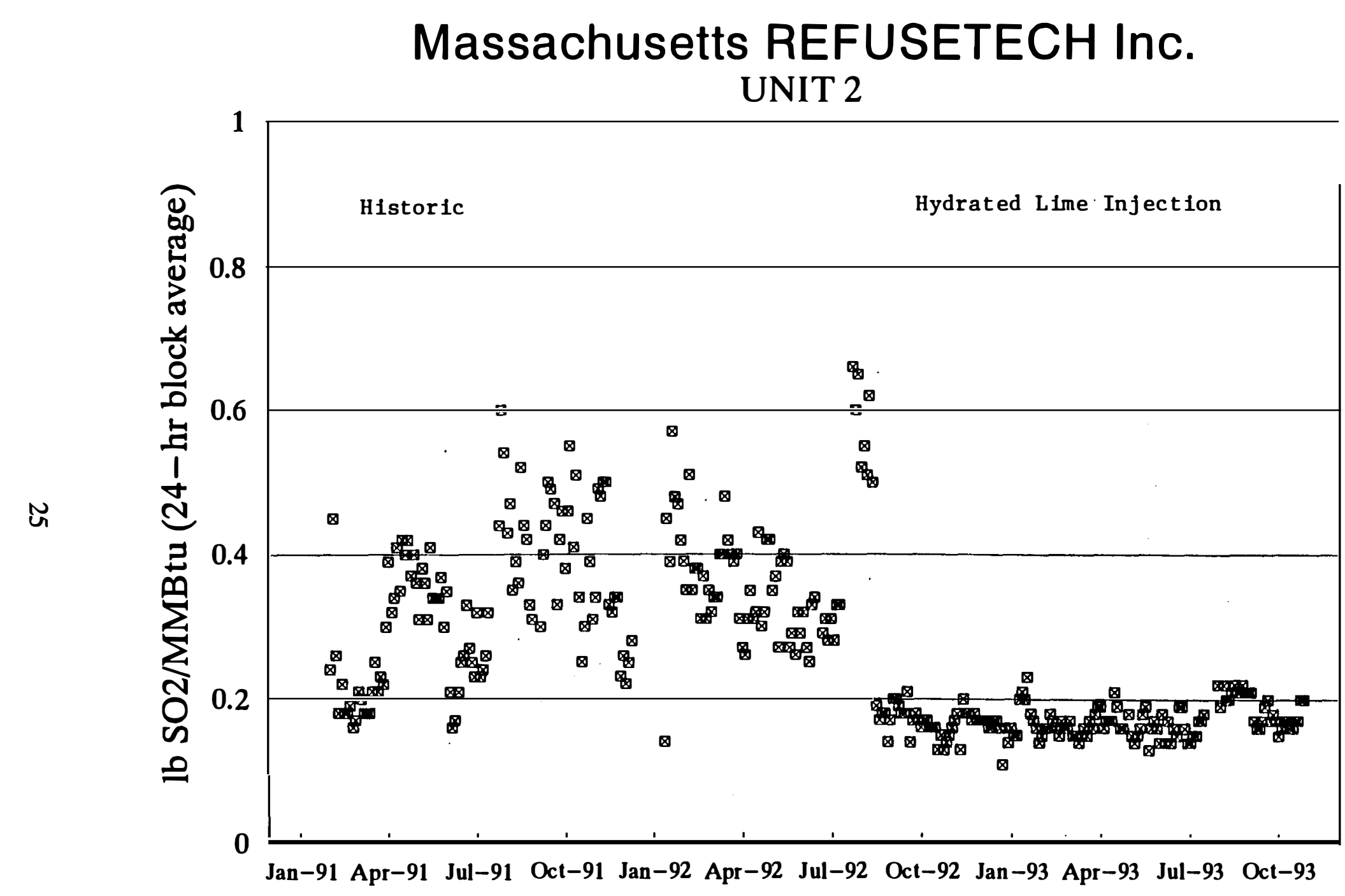

Figure 10. Comparison of Historic $\mathrm{SO}_{2}$ Emissions with $\mathrm{SO}_{2}$ Emissions During Hydrated Lime Injection 


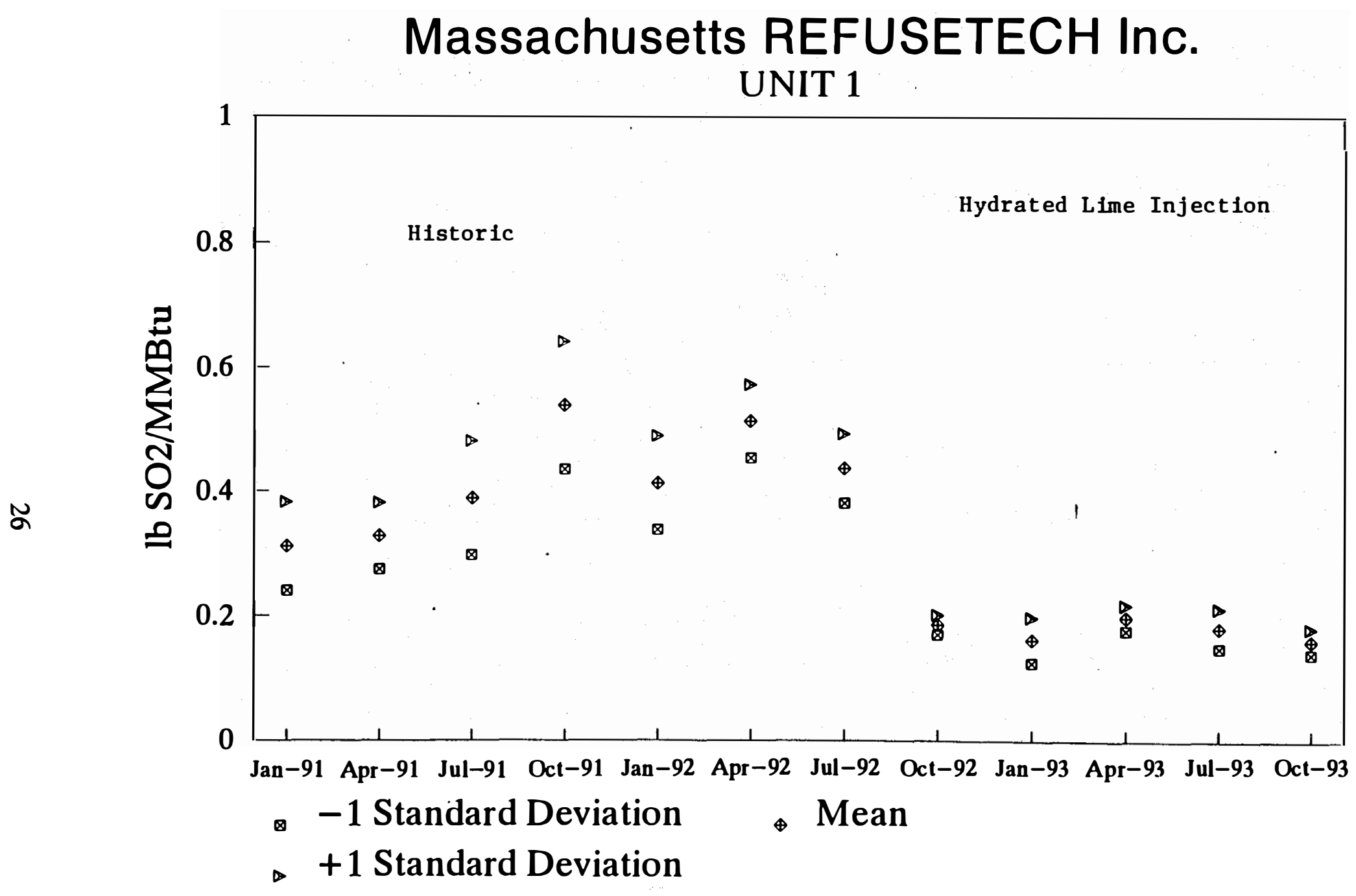

Figure 11. $\mathrm{SO}_{2}$ Emissions Varlability - Unit 1

Note: Significant Reduction in Emissions Variability Achieved During Hydrated Lime Injection 


\section{Massachusetts REFUSETECH Inc.}

\section{UNIT 2}

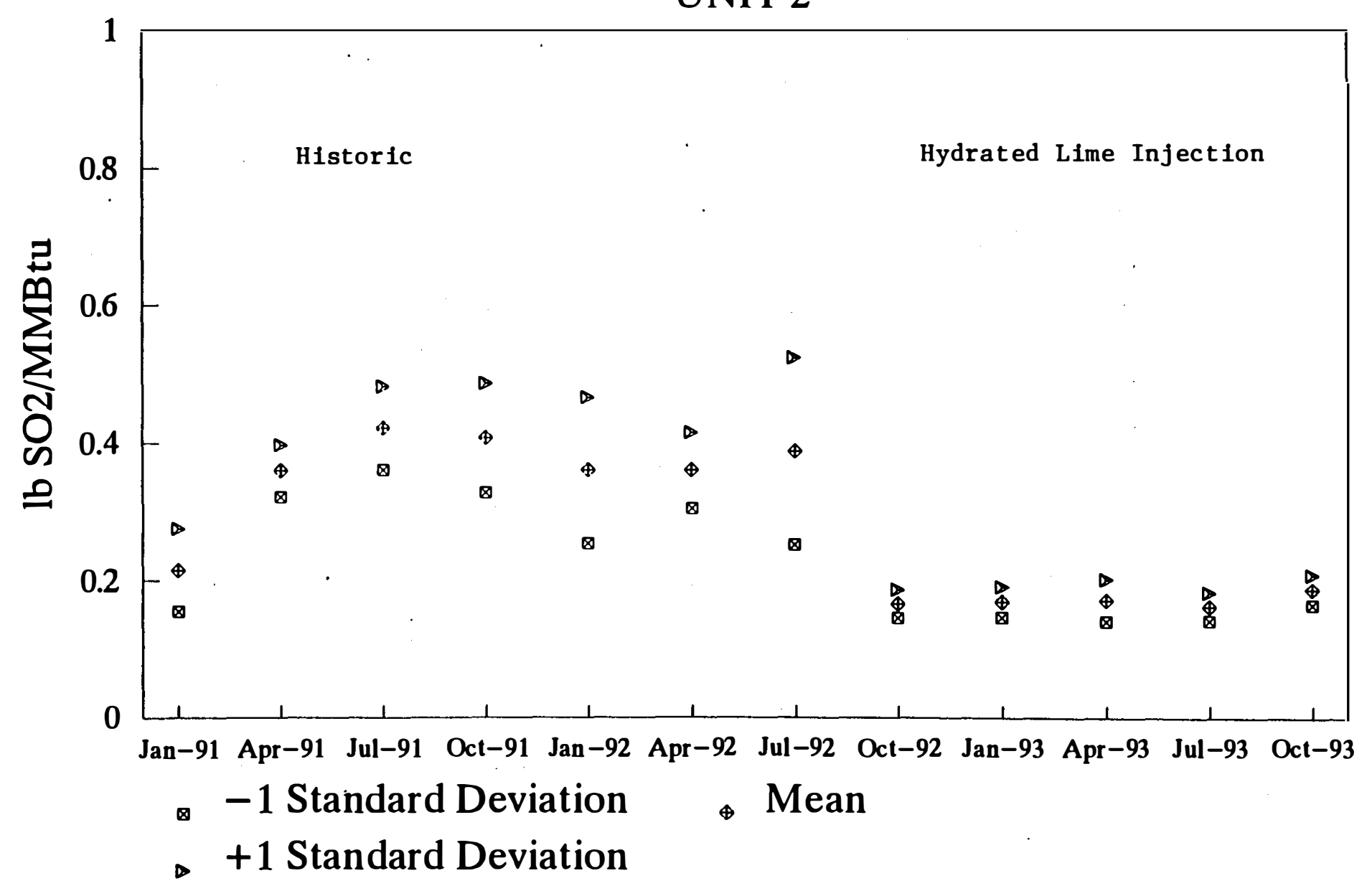

Figure 12. $\mathrm{SO}_{2}$ Emissions Variability - Unit 2

Note: Significant Reduction in Emissions Variability Achieved During Hydrated Lime Injection 


\subsubsection{Average Long-Term Lime Consumption}

Lime consumption per ton of municipal solid waste treated was monitored during the long-term test program; an average of 5.4 pounds of lime was consumed per ton of MSW processed during the program (see Table A-5).

\subsection{MANUAL STACK TEST PROGRAM RESULTS}

The results of the October 1993 manual stack test indicate that, while a minimum removal rate of $50 \%$ for $\mathrm{SO}_{2}$ emissions is achievable using furnace injection of hydrated lime, additional treatment of the flue gas may be necessary in order to meet the requirements of Emission Guidelines for a facility with a capacity of 1,100 TPD or greater. Although the system performed admirably with respect to mechanical availability and reduction in $\mathrm{SO}_{2}$ emissions, injection of hydrated lime alone or in conjunction with sodium bicarbonate did not meet all of the Emission Guidelines requirements. The $\mathrm{HCl}$ emission levels encountered during the manual stack test program were similar to $\mathrm{HCl}$ emissions levels recorded from manual stack tests performed prior to the installation of the dual sorbent injection system (Table A-2 and Figure 8). Although it has been suggested that lime furnace injection would be useful in reducing dioxin emissions ${ }^{7}$, comparisons with historic data on dioxin emissions from the REFUSETECH facility do not indicate such reductions during furnace injection of hydrated lime. Likewise, no impact on NOx nor trace metals emissions were observed. Particulate emission rates were unaffected by the injection of lime, when compared to historical levels.

The summary of results (Table A-6) shows that three run average emissions recorded during the manual stack test, for emissions other than $\mathrm{SO}_{2}$, were within the normal range of emissions experienced prior to installation of the sorbent injection system. These results indicate that hydrated lime injection has reduced $\mathrm{SO}_{2}$ emissions without impacting other emissions.

\subsection{OPERATIONAL IMPACTS}

\subsubsection{Mechanical Reliability of the System}

The mechanical reliability of the system proved better than anticipated. During the design phase it was anticipated that the system would have at least $95 \%$ mechanical reliability, and that on average, $98 \%$ mechanical reliability could be expected. The actual operation of the sorbent injection system surpassed these expectations. Maintenance of the system was performed during scheduled boiler outages. During the first year of operation, REFUSETECH has replaced one of $25 \mathrm{HP}$, single speed, AC blower motor; has replaced flexible hoses and injection nozzles; and has had to clear feed pipes plugged with sorbent. 


\subsubsection{Boiler Operational Impacts}

The injection of alkali chemical sorbents did not adversely impact short-term boiler operations. The plant operators maintained normal air flows, temperatures and other boiler operating parameters (e.g., steam flows) at normal operating levels throughout the program. However, when considering boiler impacts over a longer time period, it was discovered that the injection of alkali chemical sorbents increased boiler fouling. Boiler fouling occurs as slag accumulates on boiler walls and heat exchange tubes within the boiler architecture. The normal rate of boiler fouling is a varying function of inputs including, length of time since last boiler cleaning, average MSW throughput, composition of MSW fed to the boiler, and frequency of on-line cleaning (e.g. sootblowing). The number of factors which influence boiler fouling makes the determination of the acceleration of boiler fouling extremely difficult. However, all other things being equal, boiler fouling observed during long-term injection was greater than boiler fouling without sorbent injection.

Another operational impact that developed was the formation of slag over the hydrated lime injection nozzles which eventually caused increased back pressure in the lime feed line. This was remedied by removing the injection nozzle once per day and cleaning the slag build-up in the injection pathway. This preventative maintenance cleaning only requires one operator about ten minutes of labor and downtime per day per boiler. Such periods of downtime generally are not associated with immediate spikes in $\mathrm{SO}_{2}$ emissions. This indicates that residual lime in the furnace is reacting with $\mathrm{SO}_{2}$ during short periods of lime feed interruption.

The sodium bicarbonate injection nozzles deteriorated faster than the hydrated lime injection nozzles. Although the sodium bicarbonate nozzles were constructed of 304 stainless steel, they did not resist corrosion as well as the hydrated lime injection nozzles. The accelerated corrosion may be influenced by the amount of metal nozzle exposed to the flue gas, the temperature at the injection point, and the concentration of acid gases at the injection point. The sodium bicarbonate injection nozzles extend into the ductwork much farther (about 5 feet) than the hydrated lime injection nozzle (about 1 foot) in order to ensure dispersion of sodium bicarbonate into a turbulent area of the ductwork. Also, the temperatures that the sodium bicarbonate injections nozzles are exposed to may be significantly higher since these nozzles do not incorporate booster air which has a cooling effect; whereas the hydrated lime injection nozzles use booster air. 


\section{SECTION 7.0 \\ CONCLUSIONS AND RECOMMENDATIONS}

\subsection{HYDRATED LIME INJECTION}

Although real-time $\mathrm{SO}_{2}$ removal rates could not be determined, the data clearly shows that furnace injection of hydrated lime is effective in lowering $\mathrm{SO}_{2}$ emissions from a MWC. The data also showed an inverse relationship between lime feed rate and $\mathrm{SO}_{2}$ emissions (i.e., higher lime injection rates resulted in lower $\mathrm{SO}_{2}$ emissions). To achieve $55 \% \mathrm{SO}_{2}$ removal, the average lime consumption for each 750 TPD boiler was $5.4 \mathrm{lbs}$ lime per ton of MSW. However, consumption is dependent upon many variables including sulfur content of the MSW, changes in furnace operating temperatures, and MSW heating value variations.

This study resulted in the following conclusions:

- $\quad$ Significant reductions in $\mathrm{SO}_{2}$ emissions resulting from the use of the hydrated lime injection system, when compared to historical $\mathrm{SO}_{2}$ emission levels, were demonstrated.

- In addition to demonstrated reductions in $\mathrm{SO}_{2}$ emissions, there was a marked reduction in $\mathrm{SO}_{2}$ emissions variations (i.e., $\mathrm{SO}_{2}$ spikes). The reduced standard deviations of the data points clearly shows that the furnace sorbent injection system can effectively control $\mathrm{SO}_{2}$ emissions levels.

- $\quad$ Short term manual control injection at elevated hydrated lime feed rates (Ca:S stoichiometric ratio above 4:1) demonstrated higher than $50 \% \mathrm{SO}_{2}$ removal efficiencies. However, long-term tests were not performed at elevated hydrated lime feed rates due to operational impacts such as accelerated boiler fouling.

- No significant reductions in emissions of $\mathrm{HCl}, \mathrm{NOx}$, dioxins or trace metals were achieved using either the FSI system alone or in conjunction with the post-furnace sorbent injection system.

- $\quad$ The $\mathrm{HCl}$ levels experienced during the injection of hydrated lime into the furnace were similar to $\mathrm{HCl}$ levels experienced prior to injection of any sorbent. 


\subsection{SODIUM BICARBONATE INJECTION}

Several conclusions were made as a result of the sodium bicarbonate injection system start-up and optimization testing:

- $\quad$ Reduced lime consumption was not observed during sodium bicarbonate injection which would indicate that the sodium bicarbonate was not enhancing the removal of $\mathrm{SO}_{2}$;

- $\quad$ No significant change in $\mathrm{HCl}$ emissions levels, compared to historical $\mathrm{HCl}$ data, was experienced during the sodium bicarbonate injection program; and

- $\quad$ Attention must be paid to the equipment design and reagent specifications (e.g., particle size) to enhance reactivity and ensure free flow of sorbent throughout the feed systems.

\subsection{MWC APPLICABILITY}

The study will have limited effect on very large MWC (greater than 1,100 TPD) plants under development. These plants will be designed to meet the more stringent New Source Performance Standards for MWCs.

Existing facilities, in particular, small MWCs (250-1,100 TPD) should find the results of this study interesting and relevant. This research indicates that FSI can be useful in significantly reducing $\mathrm{SO}_{2}$ emissions. The ideal combination of temperature and retention time is likely to vary depending on furnace and boiler configuration, flue gas system design and temperature profiles in the furnace. Using this study as a base, FSI in conjunction with other acid gas controls (as intended with sodium bicarbonate during this research), may achieve the necessary reductions in acid gases and other regulated pollutants to achieve the Emission Guidelines - Subpart Ca requirements for existing MWCs. 


\section{APPENDIX A}

\section{TABLES}




\section{TABLE A-1 - MONTHLY AVERAGE $\mathrm{SO}_{2}$ EMISSIONS (FURNACE INJECTION ONLY)}

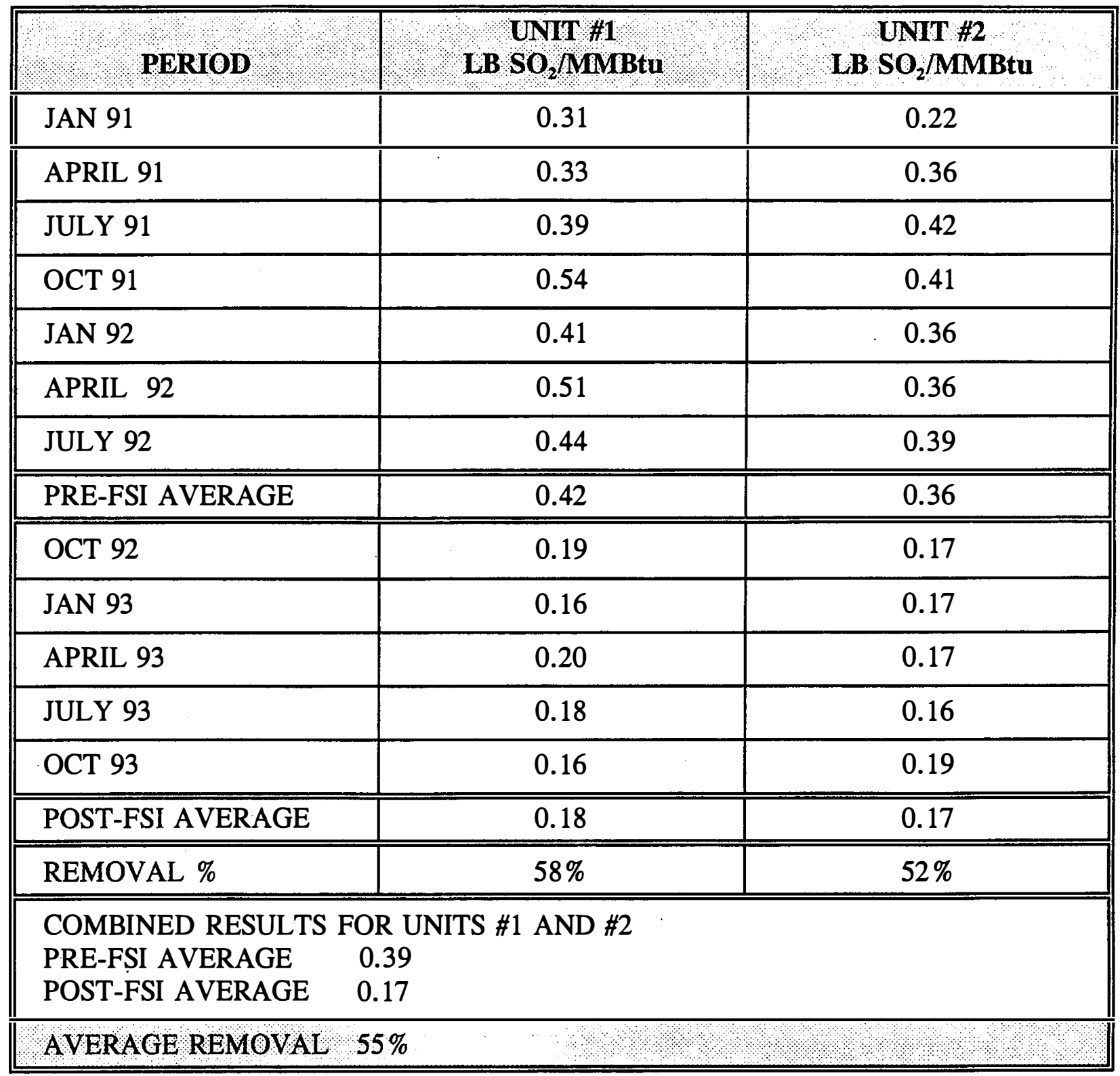


TABLE A-2 - HCl EMISSION TEST RESULTS

\begin{tabular}{||c|c|c|c|c||}
\hline \hline DATE & RUNS & $\begin{array}{c}\text { ppmvd } \\
\text { @ 7\% O }\end{array}$ & \#MMBtu & COMMENTS \\
\hline MAY 89 & 1 thru 3 & 612 & 0.845 & \\
\hline FEB 90 & 1 thru 3 & 479 & 0.662 & \\
\hline OCT 90 & 1 thru 3 & 582 & 0.805 & \\
\hline JUL 91 & 1 thru 3 & 490 & 0.676 & \\
\hline APR 92 & 1 thru 3 & 557 & 0.769 & \\
\hline & & 544 & 0.751 & Pre FSI average \\
\hline \hline JAN 93 & 1 thru 3 & 545 & 0.754 & \\
\hline OCT 93 & 1 thru 3 & 539 & 0.744 & \\
\hline MAY 93 & 1 thru 3 & 525 & 0.725 & \\
\hline \hline & & 536 & 0.740 & FSI average \\
\hline MAY 93 & 4 thru 6 & 656 & 0.906 & \\
\hline MAY 93 & 7 thru 9 & 523 & 0.722 & \\
\hline MAY 93 & 10 thru 12 & 531 & 0.733 & \\
\hline \hline & & 570 & 0.787. & Dual Sorbent Average \\
\hline \hline
\end{tabular}


TABLE A-3 - HYDRATED LIME FEEDER CALIBRATION

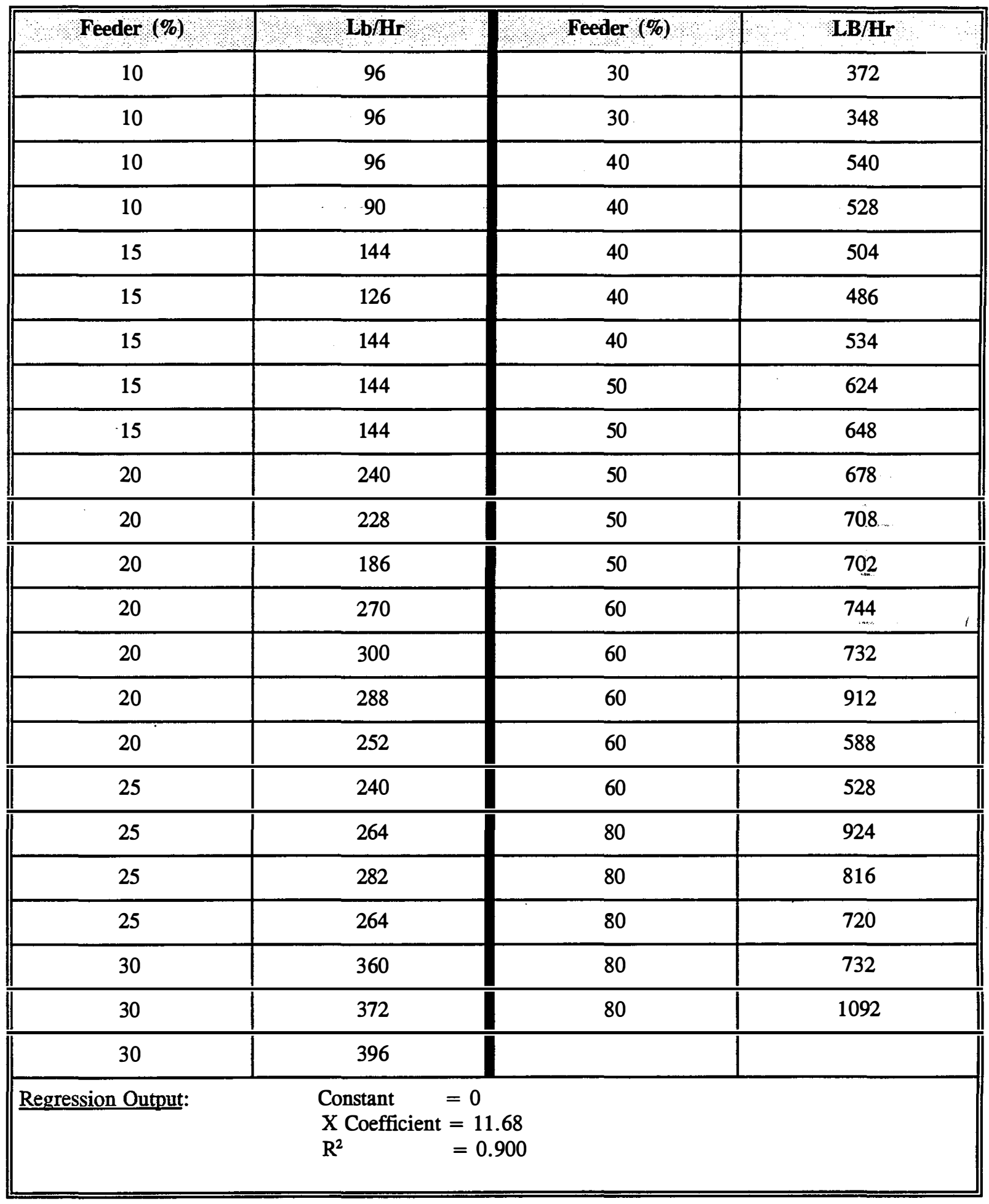


TABLE A-4 - SODIUM BICARBONATE FEEDER CALIBRATION

\begin{tabular}{||c|c||}
\hline Feeder (\%) & $\mathbf{L b} / \mathbf{h r}$ \\
\hline 25 & 330 \\
\hline 25 & 330 \\
\hline 25 & 330 \\
\hline 50 & 750 \\
\hline 50 & 765 \\
\hline 50 & 780 \\
\hline 75 & 1110 \\
\hline 75 & 1170 \\
\hline 75 & 1170 \\
\hline \hline
\end{tabular}

Regression Output:

$\begin{array}{ll}\text { Constant } & 0 \\ \mathrm{X} \text { Coefficient } & 15.17 \\ \mathrm{R}^{2} & 0.989\end{array}$


TABLE A-5 - LIME CONSUMPTION AND MSW PROCESSED (June - September 1993)

\begin{tabular}{|c|c|c|}
\hline \hline 70 Week Ending & MSW Processed & Lime Used \\
(Tons) & (Tons) \\
\hline $6 / 12 / 93$ & 9,136 & 22.0 \\
\hline $6 / 19 / 93$ & 7,770 & 22.7 \\
\hline $6 / 26 / 93$ & 7,802 & 29.0 \\
\hline $7 / 3 / 93$ & 8,297 & 33.0 \\
\hline $7 / 10 / 93$ & 8,534 & 16.0 \\
\hline $7 / 17 / 93$ & 7,584 & 15.0 \\
\hline $7 / 24 / 93$ & 8,425 & 22.0 \\
\hline $8 / 7 / 93$ & 9,167 & 20.9 \\
\hline $8 / 14 / 93$ & 8,801 & 20.9 \\
\hline $8 / 21 / 93$ & 7,942 & 18.0 \\
\hline $8 / 28 / 93$ & 7,205 & 33.4 \\
\hline $9 / 4 / 93$ & 8,479 & 15.4 \\
\hline TOTAL & 99,142 & 268.3 \\
\hline
\end{tabular}

(268.3 tons of lime $\times 2,000 \mathrm{lbs} . / \mathrm{ton})=5.4$ pounds of lime per ton 99,142 tons of MSW processed of MSW processed 
TABLE A-6 - EMISSIONS TEST RESULTS

\begin{tabular}{|c|c|c|c|}
\hline Emission & $\begin{array}{l}\text { FSI Test } \\
\text { Oct. } 93\end{array}$ & Historic Range & Units \\
\hline $\mathrm{HCl}$ & 525 & $479-612$ & ppmvd @ 7\% $\mathrm{O}_{2}$ \\
\hline TSP & 0.00145 & $0.00081-0.00789$ & gr/dscf @ 7\% O \\
\hline PCDD/PCDF & 138 & $57-187$ & ng/dscm @ $12 \% \mathrm{CO}_{2}$ \\
\hline NOx & 264 & $215-318$ & ppmvd @ 7\% $\mathrm{O}_{2}$ \\
\hline \multicolumn{4}{|l|}{ Trace Metals } \\
\hline Arsenic & 0.224 & ND (0.565) - 5.79 & $\mu \mathrm{g} / \mathrm{dscm} @ 7 \% \mathrm{O}_{2}$ \\
\hline Cadmium & 2.11 & ND (5.23) - 19.2 & $\mu \mathrm{g} / \mathrm{dscm} @ 7 \% \mathrm{O}_{2}$ \\
\hline Chromium & 8.44 & ND - 19.8 & $\mu \mathrm{g} / \mathrm{dscm} @ 7 \% \mathrm{O}_{2}$ \\
\hline Lead & 36.6 & $8.16-464$ & $\mu \mathrm{g} / \mathrm{dscm} @ 7 \% \mathrm{O}_{2}$ \\
\hline
\end{tabular}




\section{APPENDIX B}

\section{SORBENT SPECIFICATIONS}


$-40-$ 
$0 . \cdots$

\section{BRODUCT:}

IRODUCTION FACILITY:

\section{IIGII CALCIUM II YDRATEI) LIME}

Marbleton, Quebec

\section{PIRODUCTION DESCRIPTION:}

A fine white powder made by reacting quicklime with sufficient water to convert the calcium oxide to the hydroxide.

\section{COMPOSIUION ANI) TYPICAL CIIEMICAI, PROPERTIIS (ASTM C25):}

Available lime as Calcium Hydroxide $\left(\mathrm{Ca}(\mathrm{OH})_{2}\right)$

Calcium Oxide $(\mathrm{CaO})$

Available lime as calcium oxide ( $\mathrm{CaO})$

Magnesium Oxide (MgO)

Silica $\left(\mathrm{SiO}_{2}\right)$ and Insolubles

Ferric Oxide $\left(\mathrm{Fe}_{2} \mathrm{O}_{3}\right)$

Aluminat $\left(\mathrm{Al}_{2} \mathrm{O}_{3}\right)$

Total Sulphur (S) (LEC.O CS 125)

Loss on Ignition

Frce Calcium Oxide (CoO) (ASTM C911)

Calcium Carbonate ( $\left.\mathrm{CaCO}_{3}\right)$

Free Moisture $\left(\mathrm{H}_{2} \mathrm{O}\right)$

Calcium Carbonate Equivalent $\left(\mathrm{CaCO}_{3}=100\right)$ (ASTM C602)

Basicity factor $(\mathrm{CaO}=1.0)$ (ASTM C9l1)

Neutralizing coefficient @ Ph 9.0 (ASTM C400)

TYPICAI PIIYSICAL PROBERTIES:

Bulk Density $\left(\mathrm{kg} / \mathrm{m}^{3}\right)$ (ASTM C110) Packed

Loose

Specific Gravity

Solubility in Water $\left(20^{\circ} \mathrm{C}\right)$

Specific Surface (ASTM C204)

Selting rale (ASTM C110) @60 minutes

\section{SCREISN ANAI,YSIS:}

SIEVE (mm)

0.500

0.045
SIEVE (ASTM)

35

325
93.5\%

72.8

70.8

1.4

1.3

0.2

0.5

0.05

24.4

0.3

1.2

0.7

130

0.73

$11,770 \mathrm{ppm}$

$690\left(43 \mathrm{lb} / \mathrm{pi}^{3}\right)$

$320\left(20 \mathrm{lb} / \mathrm{p}^{\mathrm{i}^{3}}\right)$

2.2

$1.7 \mathrm{~g} / 1$

$24,300 \mathrm{~cm}^{2} / \mathrm{g}$ $35 \%$

RACKACING: Bulk (C.HO1OO) and Bags (CHO401)

APILICATIONS:

Hydrated lime is used in the treatment of domestic and industrial water, for treatment of sewage and industrial waste. It is also used to stabilize clay soils in highway construction, in the making of structural blocks and bricks, in the manufacture of calcium compounds, and in a wide variety of other application in the construction and agriculture industries.

The technical data contained herein is given as information only and is believed to be reliable. Graybec Calc Inc. makes no guarantec of results and assumes no obligation or liability in connection therewith. 
Grade: \#3 (U.S.P. Fine Powdered)

Product Specifications-

Granulation Guarantee

Cum. \% Retained (W/W) Minimum

Maximum

\begin{tabular}{rrrcc} 
Sieve Size & Microns & Minimum & Maximum \\
\hline USS 100 & 149 & 0 & Trace $^{*}$ \\
140 & 105 & 0 & 5 \\
200 & 74 & 0 & 20 \\
325 & 44 & 20 & 50 \\
\hline
\end{tabular}

Typical Values *

Granulation

Sieve Size Cum. \% Retained

USS 140

$<1$

200

$1 \cdot 2$

325

30

Bulk Density (lbs./ft. ${ }^{3}$ ) 56

(gms./1) 900

- Trace is less than $1 \%$ (W/W)

- Informational. not par of guaranteed specifications

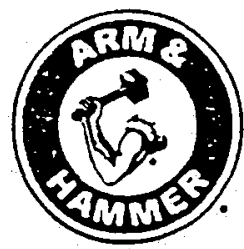

CHURCH \& DWIGT CO.. INC. CN 5297

469 North Harrison Street

Princeton. NJ 08540

$800-221-0453$
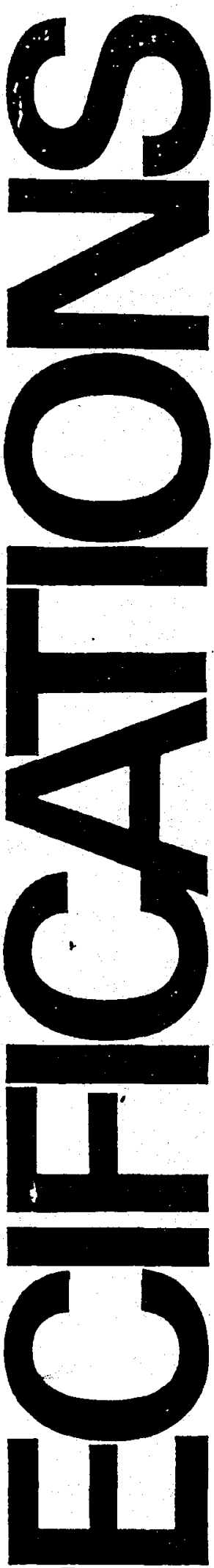

m

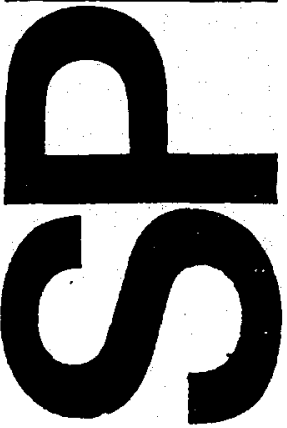


All sodium bicarbonate manu. actured by Church \& Dwight meets - or exceeds - ngid government ind industry standards. Products se $\mathrm{ng}$ the U.S.P. designation meet hw .semical specifications given in he United States Pharmacopoeia. is shown below. These specificaions insure that the product is of 1 high enough quality for use in sharmaceuticals. It also meets the ipecifications of the Food Chemcals Codex. which sets the quality or chemicals used in the food ndustry. Arm \& Hammer sodium Jicarbonate also meets the quality -equirements imposed by Federal Specifications. EE-B-87c (October 3. 1972) and O-S-576f (August 3. 19741 and the Veterans Adminis:ration Standard Specification.

Food gradequality sodium bicarbonate is classified by the food and Drug Administration as a substance "generally recognized as safe" (GRAS). Bicarib is also permissable as a component in paper and paperboard used for food packaging under 21 CFR pars 176.170 and 176.180 .

United States Pharmacopoeia (U.S.P.) Specifications: Sodium bicarbonate contains not less than $\subseteq$ percent and not more than $10 u .5$ percent of $\mathrm{NaHCO}$ calculated on a dry basis. identification: "A solution of it responds to the tests for 'Sodium. and for Bicarbonate.".

Loss on Dryng: Not more than $0.25 \%$ of its weight Insoluble Substances: "Dissolve $1 \mathrm{~g}$. in $20 \mathrm{ml}$. of water: the resulting solution is complete and clear." -

Carbonate: Meets test Ammonia: Meets test Sulfate: $150 \mathrm{ppm}$ as SO. Cloride: $150 \mathrm{ppm}$ as $\mathrm{Cl}$ Arsenic: 2 ppm Max. Heavy metals: 5 ppm Max. Assay-dry basic: Not less than $99.0 \%$ nor more than $100.5 \%$ of $\mathrm{NaHCO}_{3}$.
Food Chemicals Codex (F.C.C.)

Specifications:

Description: " $\hat{f}$ white crystalline powder. It is stable in dry aur. but slowly decomposes in moist air. Its solutions. when freshly prepared with cold water. without shaking. are alkaline to litmus. The alkalinity increases as the solutions stand. are agitated. or are heated. One gram dissolves in $10 \mathrm{ml}$. of water. It is insoluble in alcohol. A 1 in 10 solution gives positive tests for Sodium and for Bicarbonate.
Specifications:

Assay: Not less than 99\% $\mathrm{NaHCO}_{3}$ after drying.

Limits of Impurities:

Ammonia: Passes test

Arsenic (as As): Not more than 3 parts per million 10.0003 percent).

Heavy metals (as Pb): Not more than 5 parts per million (0.0005 percent).

Insoluble substances: Passes test. Loss on drying: not more than 0.25 percent by weight.

TABLE 1 General Properties of Church \& Dwight Sodium Bicarbonate

Empirical Formula:. . . . . . . . . NaHCO

CAS Number:. . . . . . . . . . . . . . . . . . . 144-55-8

Other Names.. . . . . . . . . . . . . . . Bicarbonate of soda

Sodium acid carbonate

Baking soda

Chemical Abstract Name: carbonic acid monosodium salt

Appearance:. . . . . . . . . . . White crystalline powder

Taste....................... Slightly alkaline

Molecular Weight:. ...............84.01

Thermal Decomposition:............ Decomposes without melting into $\mathrm{Na}_{2} \mathrm{CO}_{3}, \mathrm{H}_{2} \mathrm{O}$ and $\mathrm{CO}_{2}$ (see figure 1 )

Specific Density: g/cc. . . . . . . . . . . 2.22

Specific Heat: cal/g $\mathrm{g}^{\circ} \mathrm{C}$ at $22^{\circ} \mathrm{C}$.

$\mathrm{Btu} / \mathrm{lb}{ }^{\circ} \mathrm{F}$ at $72^{\circ} \mathrm{F}: . \ldots \ldots \ldots \ldots \ldots \ldots .249$

Solubility in Water:. . . . . . . . . . . . See figure 2

Solubility in Alcohol:. . . . . . . . . . . . Insoluble

Specific Gravity of Aqueous Solutions:. . See figure 3

Alkali Equivalent:.............. lb. $\mathrm{NaHCO}_{3}=0.3690$ lb. $\mathrm{Na}_{2} \mathrm{O}$

Acid Equivalent: .............. lb. $\mathrm{NaHCO}_{3}=0.432 \mathrm{lb} . \mathrm{HCl}$

Carbon Dioxide Equivalent: . . . . . . I l lb. $\mathrm{NaHCO}_{3}=0.523$ lb. $\mathrm{CO}_{2}$ pH. $1 \%$ Solution at $77^{\circ} \mathrm{F}$.............. Approximately 8.3 See figure 4
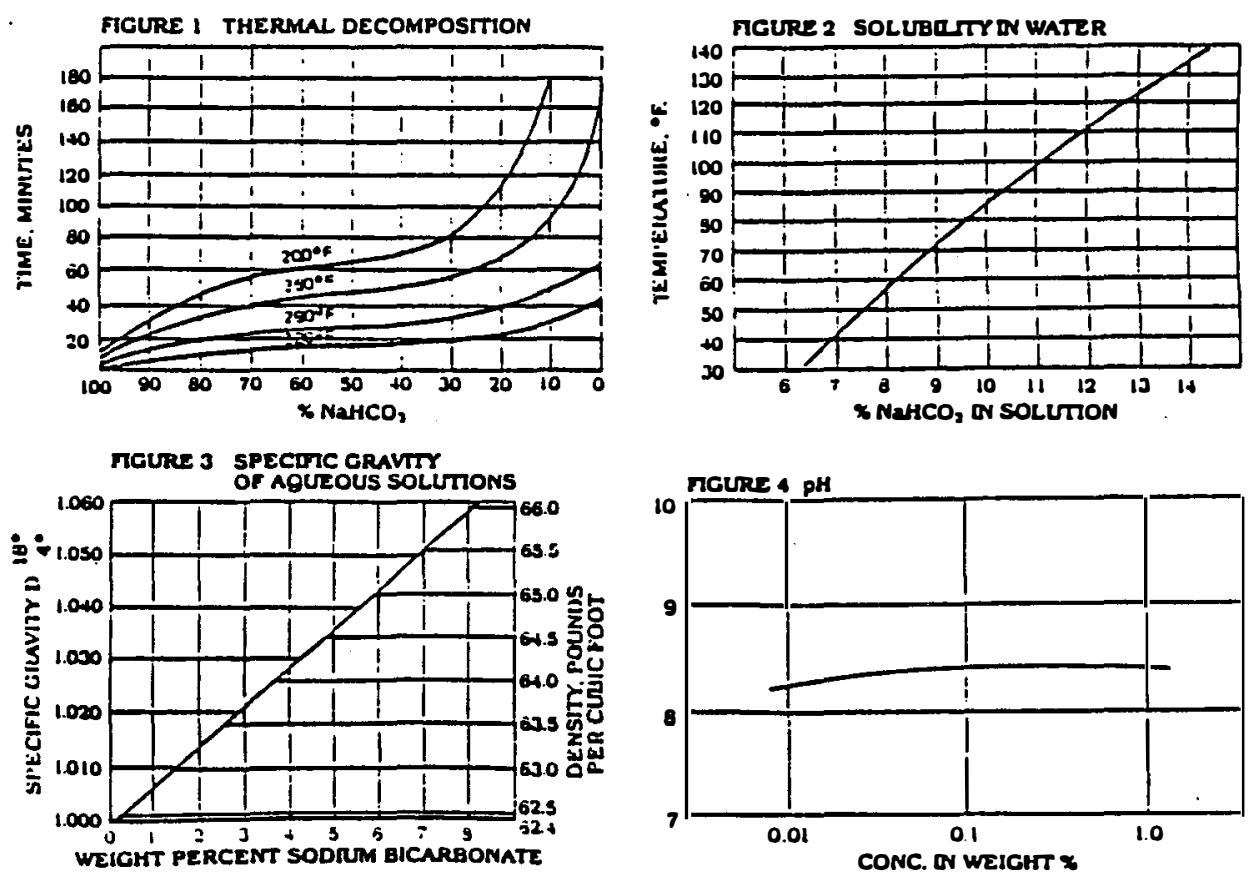
$-44-$ 


\section{REFERENCES}

1. Bjerle, I., Zhicheng, Y., and Fuming X., (1991). Studies of the Initial Stage of the High Temperature $\mathrm{CaO}-\mathrm{SO}_{2}$ Reaction, Lund University, The $1991 \mathrm{SO}_{2}$ Control Symposium.

2. Helfritch, D., Bortz, S., Beittel, R., Bergman, P. and Toole-O'Neill, B., (1991). $\mathrm{SO}_{2}$ and NOx Control by Combined Dry Injection of Hydrated Lime and Sodium Bicarbonate, The $1991 . \mathrm{SO}_{2}$ Control Symposium.

3. Verlaeten, J., Desoete, G., Ninane, L., and Blondel, J., (1991). Combined $\mathrm{SO}_{2}$ and NOx Abatement by Sodium Bicarbonate Dry Injection, Centre d'Etudes et de Recherches, Dombasle, France, The $1991 \mathrm{SO}_{2}$ Control Symposium.

4. Nakamura, H., Katsuki, Y., Kotake, S., Kagami, M., (1991). Simultaneous SOx, NOx Removal Employing Absorbent Prepared form Fly Ash, The $1991 \mathrm{SO}_{2}$ Control Symposium.

5. Frounfelker, R., (1989). Sodium Bicarbonate Makes Sense for Small Plant Retrofit. Reprinted from Solid Waste and Power, Vol. III, No. 5, October 1989.

6. Sidhu, S., and Dellinger, B., (1993). Formation and Destruction of Products of Incomplete Combustion (PIC) in Hazardous Waste Burning Cement Kilns, University of Dayton Research Institute, Dioxin '93 Symposium.

7. Gullett, B., Lemieux, P., and Dunn, J., (1993). Role of Combustion and Sorbent Parameters in Prevention of Polychlorinated Dibenzo-p-dioxin and Polychlorinated Dibenzofuran Formation During Waste Combustion, Environmental Science and Technology, Vol. 28, 1994. 


\begin{tabular}{|c|c|c|c|}
\hline $\begin{array}{l}\text { Document Control } \\
\text { Page }\end{array}$ & $\begin{array}{l}\text { 1. NREL Report No. } \\
\text { NREL/TP-430-6735 }\end{array}$ & $\begin{array}{l}\text { 2. NTIS Accession No. } \\
\text { DE94006924 }\end{array}$ & 3. Recipient's Accession No. \\
\hline \multirow{2}{*}{\multicolumn{3}{|c|}{$\begin{array}{l}\text { 4. Title and Subtitle } \\
\text { Prototype Demonstration of Dual Sorbent Injection for Acid Gas Control on } \\
\text { Municipal Solid Waste Combustion Units }\end{array}$}} & $\begin{array}{l}\text { 5. Publication Date } \\
\text { May } 1994\end{array}$ \\
\hline & & & $\cdot$ \\
\hline \multicolumn{3}{|l|}{ 7. Author(s) } & $\begin{array}{l}\text { 8. Performing Organization Rept. No. } \\
\text { NREL/TP-430-6735 }\end{array}$ \\
\hline \multirow{2}{*}{\multicolumn{3}{|c|}{$\begin{array}{l}\text { 9. Performing Organization Name and Address } \\
\text { Massachusetts Refusetech Inc. } \\
\text { Liberty Lane } \\
\text { Hampton, NH } 03842\end{array}$}} & $\begin{array}{l}\text { 10. Project/Task/Work Unit No. } \\
\text { WM4 } 11010\end{array}$ \\
\hline & & & $\begin{array}{l}\text { 11. Contract (C) or Grant (G) No. } \\
\text { (C) TR-2-11293-1 } \\
\text { (G) }\end{array}$ \\
\hline \multirow{2}{*}{\multicolumn{3}{|c|}{ 12. Sponsoring Organization Name and Address }} & $\begin{array}{l}\text { 13. Type of Report \& Period Covered } \\
\text { Subcontract Report }\end{array}$ \\
\hline & & & 14. \\
\hline \multicolumn{4}{|c|}{$\begin{array}{l}\text { 15. Supplementary Note } \\
\text { NREL technical monitor, Philip Shepherd, (303) 231-7000, x7829 }\end{array}$} \\
\hline \multicolumn{4}{|c|}{$\begin{array}{l}\text { 16. Abstract (Limit: } 200 \text { words) } \\
\text { This report gathered and evaluated emissions and operations data associated with furnace injection of dry hydrated lime and } \\
\text { duct injection of dry sodium bicarbonate at a commercial, } 1500 \text { ton per day, waste-to-energy facility. The information compiled } \\
\text { during the project sheds light on these sorbents to affect acid gas emissions from municipal solid waste combustors. The } \\
\text { information assesses the capability of these systems to meet the } 1990 \text { Clean Air Act and } 1991 \text { EPA Emission Guidelines. }\end{array}$} \\
\hline \multicolumn{4}{|c|}{$\begin{array}{l}\text { 17. Document Analysis } \\
\text { a. Descriptors } \\
\text { municipal solid waste, combustors, waste-to-energy systems, dry sorbent injection systems }\end{array}$} \\
\hline \multirow{2}{*}{\multicolumn{2}{|c|}{$\begin{array}{l}\text { 18. Availability Statement } \\
\text { National Technical Information Service } \\
\text { U.S. Department of Commerce } \\
5285 \text { Port Royal Road } \\
\text { Springfield, VA } 22161\end{array}$}} & & $\begin{array}{l}\text { 19. No. of Pages } \\
59\end{array}$ \\
\hline & & & $\begin{array}{l}\text { 20. Price } \\
\text { A04 }\end{array}$ \\
\hline
\end{tabular}

Form No. 0069E (6-30-87) 